\title{
COVID-19 (2020) Impact on air quality of the State of Kuwait
}

\author{
Jasem A Albanai ${ }^{1,2 *}$ Maryam Shehab ${ }^{1}$, Arie Vatresia ${ }^{3}$ Hassan Al-Dashti ${ }^{4}$ \\ ${ }^{1}$ Environmental Public Authority, Kuwait \\ ${ }^{2}$ Chairman's office, Public Authority for Agriculture Affairs and Fish Resources (PAAF), \\ Kuwait \\ ${ }^{3}$ Informatics Engineering, Engineering Faculty, Universitas Bengkulu, Indonesia \\ ${ }^{4}$ Meteorology Department, Directorate General of Civil Aviation, Kuwait \\ *Corresponding author: Albanay.com@gmail.com
}

\begin{abstract}
Research have been conducted in many countries around the world to assess air quality during COVID-19 pandemic, especially during lockdown period, some of these studies found an increase or decrease in some pollutants. This paper investigates the impact of COVID-19 on seven air pollutants (i.e., $\mathrm{PM}_{2.5}, \mathrm{PM}_{10}, \mathrm{NO}_{2}, \mathrm{O}_{3}, \mathrm{SO}_{2}, \mathrm{H}_{2} \mathrm{~S}, \mathrm{CO}$ ) from the period January 2020 to December 2020 in the State of Kuwait. Kuwait is a desert country located in the north-eastern part of the Arabian Peninsula, and the northeast of the Arabian Gulf (Persian as it is sometimes called). Several analytical methods were conducted, such as spatial analysis (spatial interpolation) to study the distribution of the studied variables. The data was also statistically analysed (time series analysis - Kernel density) to study the temporal changes. The analysis also included applying air quality index to the data. We found that concentrations for the pollutants decreased during the pandemic due to the decrease of anthropogenic sources including such as traffic and petroleum activities, but the concentration for $\mathrm{PM}_{2.5}$ increased, mostly because of the transported dust coming with the northwest winds prevailing in Kuwait from the Arabian deserts and Iraq.
\end{abstract}

Keywords: Kuwait; Covid-19; Air quality Index; GeoHealth; Kernel Density 


\section{Introduction}

The world currently facing the outbreak of the novel coronavirus COVID-19 pandemic (severe acute respiratory syndrome coronavirus 2 (SARS-CoV-2), which started in December 2019 in Wuhan city in China (Lu et al., 2020, Xu et al., 2020), and lead to mild to severe health effects (e.g., pneumonia) (Jiang et al., 2020) and mortality. Countries worldwide are still applying precautions and protective measures to limit the prevalence of COVID-19 (Hellewell et al., 2020, Kaplan, 2019, Quilty et al., 2020) since the WHO announce for the first time in February 2020 that the disease is caused by the new coronavirus (Cascella et al., 2020). Ministry of Health in Kuwait (MOH, 2021) announces the first COVID-19 cases in Kuwait which was in 24 February 2020, with 5 cases, and suspended all works including schools, governmental and private sectors, etc. this was the first action to limit contact between people to control the virus, with the increase of the cases, the ministry put more procedures and restrictions including full lockdown, Kuwait handled and still handling the pandemic by applying procedures and precautions to control spreading of the infection (Gasana and Shehab, 2020). Currently, instructions are applied for partial returning to normal life, such as returning to work, and travel.

Previous studies found that air pollution concentrations are associated with the increase of morbidity and mortality correlated to respiratory diseases (Adamkiewicz et al., 2004, Cui et al., 2003), lead researches to investigate the effect of air pollution on COVID-19 infection, recent studies found correlation between the increase of $\mathrm{PM}_{2.5}$ and $\mathrm{NO}_{2}$ and the risk of increase transmission of COVID-19 (Sasidharan et al., 2020). A study conducted in Italy, Spain, France and Germany reported that long-term exposure to higher concentrations of $\mathrm{NO}_{2}$ may contribute to mortality caused by COVID-19 (Ogen, 2020). Long-term exposure to $\mathrm{PM}_{2.5}$ by $1 \mu \mathrm{g} / \mathrm{m} 3$ also found to be significantly associated with increase of $8 \%$ of COVID-19 mortality (Wu et al., 2020). On the short-term exposure, (Zhu et al., 2020) reported that pollutants namely $\mathrm{PM}_{2.5}$, $\mathrm{PM}_{10}, \mathrm{CO}, \mathrm{NO}_{2}$ and $\mathrm{O}_{3}$ are significantly associated with the infection of COVID-19, but not for $\mathrm{SO}_{2}$ in China (Zhu et al., 2020).

In Kuwait, natural and anthropogenic air pollution sources are both local (e.g. oil refineries, traffic, dust, chemical manufacturing, water treatment and electricity plants) and transported (e.g. dust, fossil fuel burning from Iraq) (Al-Hemoud et al., 2019), causing concentrations of some pollutants exceed the WHO guidelines limits such as $\mathrm{PM}_{10}$ (Alolayan et al., 2012, Alomair et al., 2013, Neelamani et al., 2015, Brown et al., 2008) and $\mathrm{PM}_{2.5}$ (Alolayan et al., 2012, Neelamani et al., 2015, Al-Hemoud et al., 2019, Brown et al., 2008), where between February 2004 and October $2005 \mathrm{PM}_{2.5}$ found to be $53 \mu \mathrm{g} / \mathrm{m} 3$, exceeding WHO guidelines. According to Alolayan et al., 2012, high levels of $\mathrm{PM}_{2.5}$ from local anthropogenic sources includes traffic, combustion of oil, and emissions from photochemical works, however, more than $50 \%$ of ambient $\mathrm{PM}_{2.5}$ are caused by natural sources most of it originating from transported sources. Anthropogenic transported sources also contribute to Kuwait ambient $\mathrm{PM}_{2.5}$ including traffic and smelters.

Studies on air pollution before COVID-19 reached Kuwait and before procedures applied to limit human contact shows that they can exceed guidelines limits. According to Alhaddad et al., 2015, oil fields, traffic and oil refineries contribute significantly to higher concentrations of the pollutants $\mathrm{SO}_{2}$, VOCs, $\mathrm{NO}, \mathrm{CO}$, and $\mathrm{CO}_{2}$. On another study, $\mathrm{SO}_{2}$ found to have high 
concentrations exceeding US EPA standards, and that increase in population density, motor vehicles, industrial activities, and power plants contribute to higher concentrations of $\mathrm{SO}_{2}$ and NOx (Al-Baroud et al., 2017), while (Brown et al., 2008) found that the higher concentrations of $\mathrm{Pb}, \mathrm{Zn}, \mathrm{Cu}$, and $\mathrm{Mn}$ in urban areas are related to traffic. Ozon $\left(\mathrm{O}_{3}\right)$ concentrations in Kuwait found to be at its highest during summer (A-Rashidi et al., 2018, Yassin et al., 2018) where found to be the highest in urban areas (20 to $25 \mu \mathrm{g} / \mathrm{m} 3$ ) (Yassin et al., 2018), and during spring (i.e., March and April) and late summer (i.e., September) (Abdul-Wahab et al., 2000). Sulphur dioxide $\left(\mathrm{SO}_{2}\right)$ and nitrogen dioxide $\left(\mathrm{NO}_{2}\right)$ pollutants levels found to be higher during summer (i.e., June-September), due to emissions from power plant created by using air conditioning extensively during these months (Abdul-Wahab et al., 2000), and also found to be the highest in urban areas, where $\mathrm{NO}_{2}$ tropospheric vertical column is $53 \%$ above the median urban level of $28.13 \times 1014$ molecules $\mathrm{cm}^{-} 2$, and $\mathrm{SO}_{2}$ is $490 \%$ above the average urban Level (Barkley et al., 2018). In study for Al-Awadhi and Yassin, $2010 \mathrm{SO}_{2}$ hourly concentration in residential areas found to be $380 \mu \mathrm{g} / \mathrm{m} 3$, exceeding the hourly air quality limit values for both Kuwait EPA (170 ppb, $444 \mu \mathrm{g} / \mathrm{m} 3)$ and EU standards $(350 \mu \mathrm{g} / \mathrm{m} 3)$. A study by (Alsaber et al., 2020) in Kuwait found that human exposure to $\mathrm{NO}_{2}$ and $\mathrm{SO}_{2}$ are significantly correlated with rheumatoid arthritis. Carbon monoxide (CO) highest mean found during October (1.43 ppm), February (0.93 ppm), and June (0.74 ppm) (Abdul-Wahab et al., 2000), (Alhajeri et al., 2019) study predicted that emission levels of CO expected to increase by $71.8 \%$ by the year 2030 compared to 2015 levels.

Studies around the world have been conducted to investigate the effect of COVID-19 on air quality, some of these studies found that during COVID-19 air pollutants concentrations decreased such as $\mathrm{NO}_{2}$ (Chossiere et al., 2021, Ji and Chang, 2020, Sannino et al., 2020), $\mathrm{PM}_{10}$ (Anil and Alagha, 2021, Aljahdali et al., 2021, Şahin, 2020, Broomandi et al., 2020), both $\mathrm{PM}_{10}$ and $\mathrm{PM}_{2.5}$ (Collivignarelli et al., 2020, Garg et al., 2020, Ji and Chang, 2020, Kerimray et al., 2020, Mahato et al., 2020, Menut et al., 2020, Shakoor et al., 2020, Tobías et al., 2020), CO, $\mathrm{SO}_{2}$ (Garg et al., 2020, Sannino et al., 2020), NO and NOx (Garg et al., 2020), $\mathrm{NH}_{3}$, and $\mathrm{C}_{6} \mathrm{H}_{6}$ (Garg et al., 2020). However, concentrations of some pollutants increased such as $\mathrm{O}_{3}$ (Garg et al., 2020, Ji and Chang, 2020) and $\mathrm{SO}_{2}$ (Ji and Chang, 2020), $\mathrm{PM}_{10}$ (Hashim et al., 2020, Shakoor et al., 2020) due to either anthropogenic sources or dust events.

A study for (Albassam et al., 2009) on pollution from traffic near schools found highest levels of $\mathrm{CO}$ and $\mathrm{NO}_{2}$ during morning and afternoon during weekdays, and lowers levels during weekends, maximum daily mean concentrations reached $2.6 \mathrm{ppm}$ for $\mathrm{CO}, 46.7 \mathrm{ppb}$ for $\mathrm{NO}_{2}$ during February. Measurements taken from the period 2012-2017 shows that daily concentrations of $\mathrm{SO}_{2}, \mathrm{NO}_{2}$ and $\mathrm{PM}_{10}$ have exceeded the Kuwait environmental public authority (EPA) guidelines in both residential and industrial areas, where these pollutants in the residential areas are coming from industrial activities and vehicles, meteorological conditions (e.g., temperature, humidity) also affect the increase concentrations of these pollutants (AlHurban et al., 2021), $\mathrm{H}_{2} \mathrm{~S}$ concentrations found to be higher in urban areas near petroleum work facilities (Al-Salem and Khan, 2008).

In this research, we will investigate the air quality during the COVID-19 pandemic in Kuwait, to assess and find the correlation between air pollution concentrations and the effect of the 
decrease of anthropogenic activities, moreover, the effect of air pollution concentrations namely particulate matter $\leq 2.5$ micrometres in diameter $\left(\mathrm{PM}_{2.5}\right)$, particulate matter $\leq 10$ micrometres in diameter $\left(\mathrm{PM}_{10}\right)$, nitrogen dioxide $\left(\mathrm{NO}_{2}\right)$, Ozon $\left(\mathrm{O}_{3}\right)$, sulphur dioxide $\left(\mathrm{SO}_{2}\right)$, hydrogen sulphide $\left(\mathrm{H}_{2} \mathrm{~S}\right)$, and carbon monoxide $(\mathrm{CO})$.

\section{Study area}

The State of Kuwait is located in the northeast of the Arabian Peninsula, where it is bordered by Iraq to the north and Saudi Arabia to the west and south. Kuwait has a coastal strip located on the north-western part of the Arabian Gulf (Fig. 1). The total population of Kuwait is more than 4.5 million people (Albanai, 2021a), all of these residents are concentrated in Kuwait urban area, where almost all of the activities are concentrated. Kuwait includes six governorates: AlAsimah, Hawalli, Al-Farawaniyah, Al-Jahra, Mubarak Al-Kabeer, Al-Ahmadi.

Most of Kuwait's lands are flat, and with its location under the influence of the subtropical high pressure, it is thus one of the hottest regions in the world. The temperature in the summer exceeds 50 degrees Celsius, while in the winter it drops to below 7 degrees, and thus it is characterized by a wide temperature range between summer and winter (Albanai, 2019; Albanai, 2020). Kuwait has an arid climate which is characterized by air-born dust (Thuraya M Saeed \& Al-Dashti, 2011). Dust event is one of the common weather and climate phenomena in Kuwait. Belt dust storms intensify in the summer, along the north-western winds, while these strong dust-laden winds ease in the winter. Low average annual rainfall (114-118 mm), minimum annual levels have been recorded as low as 31.3 millimetres (Aldashti et al., 2012), and very high average temperature Mitribah, Kuwait observation be accepted as $53.9 \mathrm{C}$ (Merlone et al., 2019), causes more appearance of dust event in summer and spring. The annual average wind speed ranges between $4.5 \mathrm{~m} / \mathrm{s}$ and $6.13 \mathrm{~m} / \mathrm{s}$ (Alkhalidi et al., 2019). In Kuwait northwest winds are dominant (Neelamani et al., 2014).

The major dust sources are located in North and North - West of Kuwait. Dust sources are the Mesopotamian region that includes Syria, Iraq, western Iran, and the north-eastern portion of the Arabian Peninsula (Aldashti et al., 2019). Dust storms (SYNOP WW code: 09) (DS) are the result of turbulent winds raising large quantities of dust into the air and reducing visibility to less than $1000 \mathrm{~m}$, and Blowing dust (BLUD) (SYNOP WW code: 07 ) is raised by winds to moderate heights above the ground reducing visibility at eye level $(1.8 \mathrm{~m})$ but not less than $1000 \mathrm{~m}$, and finally Dust haze (DU) (SYNOP WW code: 06) is produced by dust particles in suspended transport which have been raised from the ground by a dust storm prior to the time of observation (McTainsh \& Pitblado, 1987).

Most of the dust source regions causing dust storm events are dominated by the large-scale synoptic weather systems, where a strong wind associated with the large low-level pressure gradient causing the dust emission and transport. During June, July and August, strong inflow in to North West of Kuwait pass over sources of the dust region brings the dust storm over Kuwait. The natural funnelling of large air masses by high mountains in Turkey and Iran, combined with the high plateaus in Saudi Arabia, help to funnel air across the Mediterranean 
into the Arabian (Persian) Gulf. The Arabian Peninsula is one of the five major sources of mineral dust around the globe (T M Saeed et al., 2014). Due to the region's aridity, frequent dust events have been associated with higher concentrations of PM 2.5 and PM 10 in Kuwait (Al-Hemoud et al., 2018; Yuan et al., 2020).

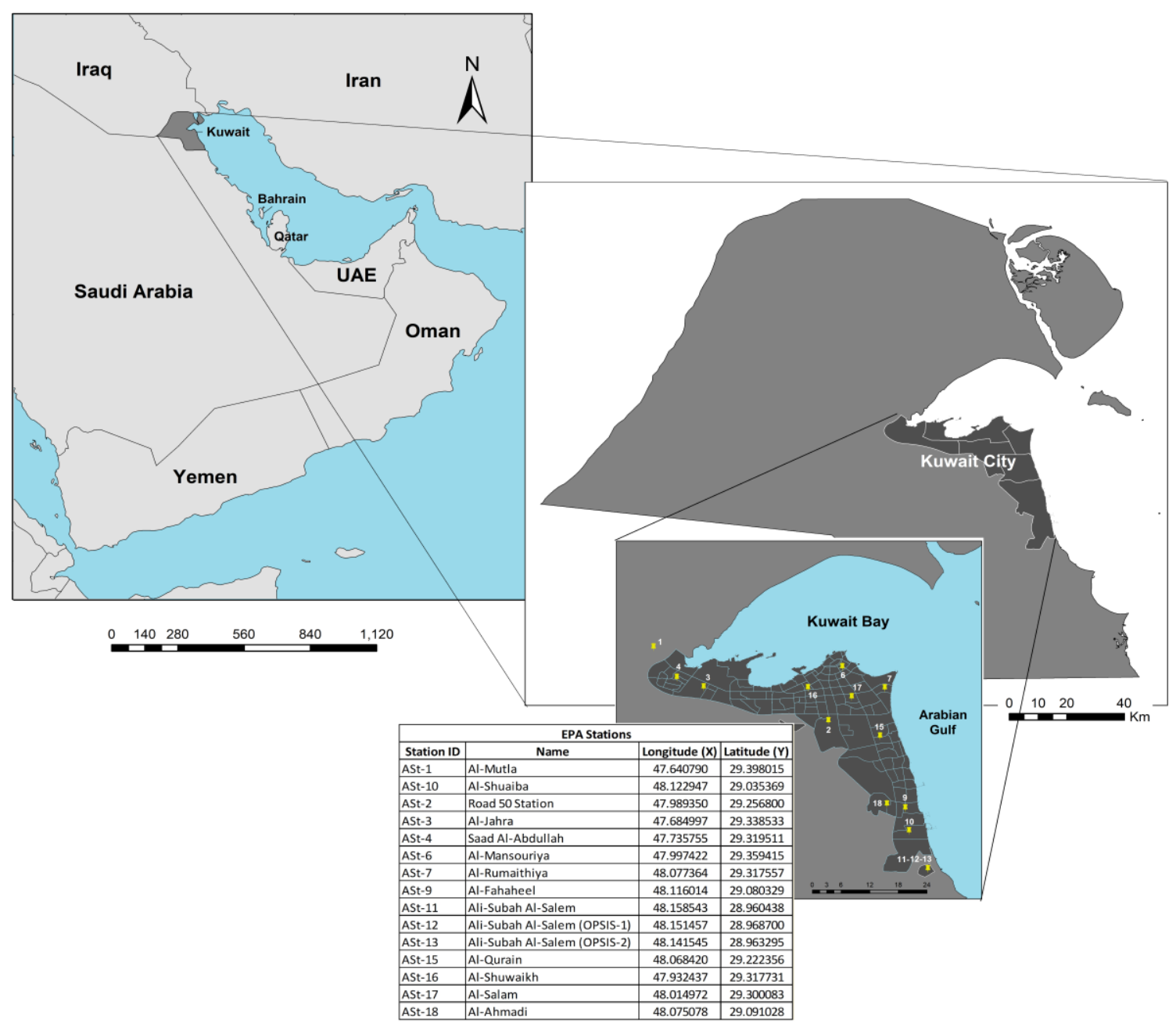

Fig. 1. The State of Kuwait, the urban area the Kuwait and KEPA air quality monitoring stations locations and information.

\section{Material \& methods}

\subsection{Data description}

The field data used in this study refer to the air quality monitoring stations of the Kuwait Environmental Public Authority (KEPA). These stations were established by KEPA to monitor air quality in Kuwait, and maintaining the current rates of various air quality variables at safe and permissible limits. The network of stations specialized in monitoring air quality was established in 1984 (Albanai, 2021b). It provides data around the clock since that time. The number of stations has grown to thirteen fixed stations today. KEPA receives data and stores it automatically on its computers. The stations are distributed geographically to different regions 
of the country, where most of them are located in the residential suburbs of the governorates of the State of Kuwait (Fig. 1). The stations measure the different concentrations of air quality measurement variables, both natural and those that emit through human activity. The variables include readings of nitrogen dioxide, sulfur dioxide, ground-level ozone, carbon monoxide, and Particulate Matter-2.5 and 10 microns ( $\mathrm{PM}_{2.5}$ and $\left.\mathrm{PM}_{10}\right)$. KEPA provides readings around the clock via its website (Environment Public Authority, 2020). In this study, air quality data of 2020 referred to KEPA were used (Fig. 2).

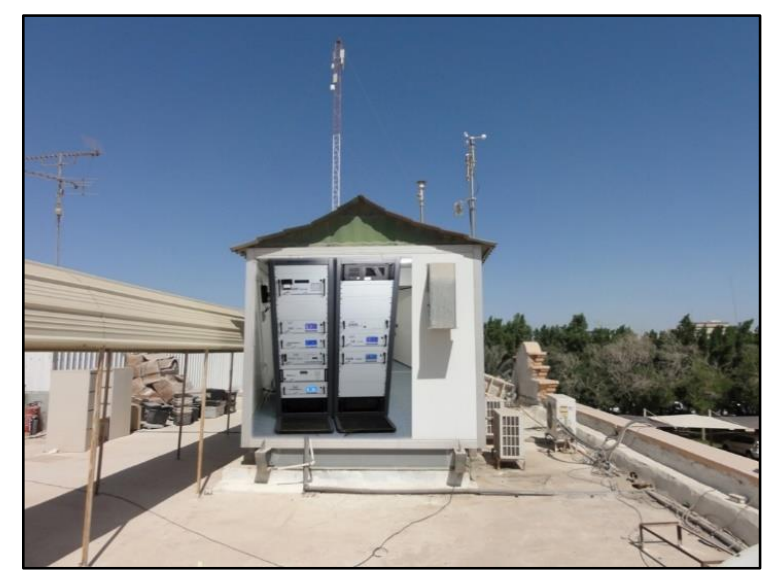

Fig. 2. Al-Qurain air quality fixed station (Environment Public Authority, 2020).

\subsection{Spatial analysis}

The monthly averages of the air quality variables for 2020 were extracted in Kuwait urban area. A spatial derivation model called the inverse distance weighted (IDW) was built based on the monthly averages extracted from the stations for 2020 between January and December, to compare the spatial and temporal distribution. The model applied using ArcGIS Pro 2.1 software depending on the number of points entered, using only the geographical area covered by Kuwait urban area, as a specific range for the derivation. The IDW is a way to estimate an unknown point value from several surrounding known point values. The best results for this model are obtained when the distribution of control points (samples) is of high density and has a wide spatial spread over the study area concerned, to simulate all existing spatial differences; otherwise, the results of the model may be affected (Watson \& Philip, 1985). The IDW technique provides better accuracy in the spatial enhancement of the raster model with conditions of high values of coefficient of variation, strong anisotropy and spatial structure (Chaplot et al., 2006). Additionally, Musashi et al. (Musashi et al., 2018) showed more accuracy for this model than other derivative models. This technique was applied by some studies to increase the spatial resolution of the geographic data (Albanai, 2021b). The following algorithm is used to calculate the inverse distance weighted (IDW) model: 


$$
z x_{0}=\sum_{i=1}^{n} x_{i} / h_{i j}^{\beta}+\sum_{i=1}^{n} 1 / h_{i j}^{\beta}
$$

\section{(Equation 1)}

Where $z\left(x_{0}\right)$ is the output value, $x_{i}$ is the value of control known points, hij is the separation distance between the interpolated value and the control points value, and $\beta$ is the weighting power, $n$ is the total number of the control points (samples) values.

\subsection{Statistical analysis}

We plot the daily data of the gasses occurrences over Kuwait using Generalized Additive Modelling (GAM) algorithm. Generalized Additive Model (GAM) is an extension or generalization of GLM by replacing linear form with additive form (Ruppert, 2004; Wood, 2011). GAM is a smooth function that will be estimated using the Kernel estimator. To estimate an additive nonparametric regression model with a Poisson distributed response based on a kernel estimator, a local scoring algorithm was used, by programming the R software (Wood, 2006).

On the other hand, the Air Quality Index of Kuwait was analysed. The Air Quality Index is an easy and simple way to inform the public about the status and quality of air in the areas surrounding the air quality monitoring stations distributed. The purpose of the Air Quality Index is to understand what the surrounding air quality means for public health. The Index also explains how clean or unhealthy the air is, and the associated health effects that may represent a problem and concern, and what measures and precautions should be taken (Environment Public Authority, 2011).

Air Quality Index as a scale from 0 to 500, where the value 100 refers to the Kuwait National Ambient Air Quality Standard for air pollutants, which is the level set by KEPA in Kuwait to protect public health. As long as the pollutant concentrations are lower and below the national standards, then the air quality can be considered good and acceptable, and the higher the value of the air quality index, the higher the level of air pollution above the national standards and thus the greater concern about its impact on health. To simplify the matter, the Air Quality Index has been divided into six levels with different colours and values, as shown in Table 1. 
Table. 1. Kuwait air quality index values, levels, effects and category (Environment Public Authority, 2011).

\begin{tabular}{|c|c|c|c|c|}
\hline $\begin{array}{c}\text { KAQI } \\
\text { Category }\end{array}$ & $\begin{array}{l}\text { KAQI } \\
\text { Value }\end{array}$ & Air Pollution Level & Health Effects & $\begin{array}{l}\text { Cautionary Procedures } \\
\text { (for } \mathrm{PM}_{2.5} \text { ) }\end{array}$ \\
\hline Good & $0-50$ & $\begin{array}{l}\text { The air quality considered } \\
\text { to be good. Concentrations of all air } \\
\text { pollutants are well below the } \\
\text { National Air Quality Standards } \\
\text { (NAQS) }\end{array}$ & Air pollution poses little or no risk & None \\
\hline Acceptable & $51-100$ & $\begin{array}{l}\text { Air quality is acceptable. Levels of } \\
\text { air pollutants are still within the } \\
\text { National Ambient Air Quality } \\
\text { Standards (NAQS) with no reported } \\
\text { exceedances. }\end{array}$ & $\begin{array}{l}\text { For some pollutants there may be a } \\
\text { little health concern for a very small } \\
\text { number of people who are } \\
\text { unusually sensitive to air pollution. }\end{array}$ & $\begin{array}{l}\text { People with respiratory disease, } \\
\text { such as asthma, should limit } \\
\text { prolonged outdoor activities }\end{array}$ \\
\hline Moderate & $101-150$ & $\begin{array}{l}\text { The air quality is moderate, where } \\
\text { limited/marginal exceedances above } \\
\text { of the National Air Quality Standards } \\
\text { (NAQS) have been reported. }\end{array}$ & $\begin{array}{l}\text { Unhealthy for Sensitive Groups. } \\
\text { Members of sensitive groups may } \\
\text { experience health effects, however, } \\
\text { the general public is not likely to be } \\
\text { affected }\end{array}$ & $\begin{array}{l}\text { Active children and adults, and } \\
\text { people with respiratory disease, } \\
\text { such as asthma, should limit } \\
\text { prolonged outdoor activities }\end{array}$ \\
\hline Bad & $151-200$ & $\begin{array}{l}\text { The air quality is bad, where many } \\
\text { exceedances above of the National } \\
\text { Air Quality Standards (NAQS) have } \\
\text { been reported. }\end{array}$ & $\begin{array}{l}\text { Unhealthy. Everyone may begin to } \\
\text { experience health effects; members } \\
\text { of sensitive groups may experience } \\
\text { more serious health effects }\end{array}$ & $\begin{array}{l}\text { Active children and adults, and } \\
\text { people with respiratory disease, } \\
\text { such as asthma, should avoid } \\
\text { prolonged outdoor activities; } \\
\text { everyone eise, especially children, } \\
\text { should limit prolonged outdoor } \\
\text { activities }\end{array}$ \\
\hline Very bad & $201-300$ & $\begin{array}{l}\text { The air pollution level is very bad, } \\
\text { where significant high exceedances } \\
\text { above the National Air Quality } \\
\text { Standards (NAQS) have been } \\
\text { recorded. }\end{array}$ & $\begin{array}{l}\text { Very unhealthy. Health warnings of } \\
\text { emergency conditions. The entire } \\
\text { population is more likely to be } \\
\text { affected. }\end{array}$ & $\begin{array}{l}\text { Active children and adults, and } \\
\text { people with respiratory disease, } \\
\text { such as asthma, should avoid all } \\
\text { outdoor activities; everyone else, } \\
\text { especially children, should limit } \\
\text { outdoor activities. }\end{array}$ \\
\hline Hazardous & $301-500$ & $\begin{array}{l}\text { The air pollution level is Hazardous, } \\
\text { and becomes hazardous to human } \\
\text { health }\end{array}$ & $\begin{array}{l}\text { Health alert: everyone may } \\
\text { experience more serious health } \\
\text { effects }\end{array}$ & $\begin{array}{l}\text { Everyone should avoid all outdoor } \\
\text { exertion }\end{array}$ \\
\hline
\end{tabular}

The Index is calculated for six air pollutants according to the Environmental Protection Law No. 42/2014 and its implementing instructions (Decision No. 8 of 2017) according to which KEPA has set air quality standards to protect public health, and these pollutants are: Fine particles - 2.5 microns in diameter $\left(\mathrm{PM}_{2.5}\right)$, Fine particles - 10 microns in diameter (PM-10), Nitrogen dioxide $\left(\mathrm{NO}_{2}\right)$, Ozone $\left(\mathrm{O}_{3}\right)$, Sulfur dioxide $\left(\mathrm{SO}_{2}\right)$, Carbon monoxide $(\mathrm{CO})$ (Table 2).

Table. 2. National Ambient air quality standard in the state of Kuwait (Environment Public Authority, 2011). 


\begin{tabular}{|c|c|c|c|c|}
\hline Pollutant Name & Symbol & Duration of Exposure & National Limit & Unit of Concentration \\
\hline \multirow{2}{*}{ Sulphur Dioxide } & \multirow{2}{*}{$\mathrm{SO}_{2}$} & 1 Hour & 0.075 & Parts per million (ppm) \\
\hline & & 24 Hours & 0.019 & Parts per million (ppm) \\
\hline \multirow{2}{*}{ Nitrogen Dioxide } & \multirow{2}{*}{$\mathrm{NO}_{2}$} & 1 Hour & 0.100 & Parts per million (ppm) \\
\hline & & Annual & 0.021 & Parts per million (ppm) \\
\hline Carbon Monoxide & co & 1 Hour & 35.00 & Parts per million (ppm) \\
\hline Ozone & $\mathrm{O}_{3}$ & 8 Hour & 0.07 & Parts per million (ppm) \\
\hline $\begin{array}{l}\text { Particulate Matter } \\
10 \text { Micron }\end{array}$ & $\mathrm{PM}_{10}$ & 24 Hours & 350 & $\begin{array}{l}\text { Micrograms per cubic } \\
\text { meter }\left(\mu \mathrm{g} / \mathrm{m}^{3}\right)\end{array}$ \\
\hline $\begin{array}{l}\text { Particulate Matter } \\
2.5 \text { Micron }\end{array}$ & $\mathrm{PM}_{2.5}$ & 24 Hours & 75 & $\begin{array}{l}\text { Micrograms per cubic } \\
\text { meter }\left(\mu \mathrm{g} / \mathrm{m}^{3}\right)\end{array}$ \\
\hline
\end{tabular}

When the air quality index for one of the pollutants above exceeds the value of 100, then the air condition is initially considered unhealthy for sensitive groups who suffer from respiratory diseases such as asthma, and then if the index rises above 151, the air quality becomes unhealthy for all, and the higher the air quality index becomes, the effects of the pollutants become more dangerous. The air quality index was calculated for each of the six pollutants mentioned above $\left(\mathrm{PM}_{2.5}, \mathrm{PM}_{10}, \mathrm{NO}_{2}, \mathrm{O}_{3}, \mathrm{SO}_{2}\right.$, and $\left.\mathrm{CO}\right)$, using the following relationship that was developed by the US Environmental Protection Agency to calculate the air quality index for each pollutant:

$$
I_{p}=\frac{I_{H i}-I_{L o}}{B P_{H I}-B P_{L o}}\left(C_{p}-B P_{L o}\right)+I_{L o}
$$

(Equation 2)

Where

$I_{p}=$ the index for pollutant $\mathrm{p}$

$C_{p}=$ the rounded concertation of pollutant $\mathrm{p}$

$I_{H i}=$ the AQI value corresponding to breaking point high $(\mathrm{BP} \mathrm{Hi})$

$I_{L o}=$ the AQI value corresponding to breaking point low (BP Lo)

$B P_{H I}=$ the breakpoint that is greater than or equal to $\mathrm{Cp}$

$B P_{L o}=$ the breakpoint that is less than or equal to $\mathrm{Cp}$

The monthly averages of the six gases concentrations were analysed, then they were classified as stated in Table 3, and thus they had a standardized scale. The six variants after being categorized from good to hazardous. 
Table. 3. Low and high breaking points for the calculation of the hourly air quality index for each pollutant (Environment Public Authority, 2011).

\begin{tabular}{|c|c|c|c|c|c|c|c|c|c|c|c|c|c|c|c|c|}
\hline & & & \multicolumn{2}{|c|}{$\mathrm{SO}_{2}$} & \multicolumn{2}{|c|}{$\mathrm{NO}_{2}$} & \multicolumn{2}{|c|}{$\mathrm{O}_{3}$} & \multicolumn{2}{|c|}{$\mathrm{O}_{3}$} & \multicolumn{2}{|c|}{ CO } & \multicolumn{2}{|c|}{$\mathrm{PM}_{2.5}$} & \multicolumn{2}{|c|}{$\mathrm{PM}_{10}$} \\
\hline KAQI & & & BPLO & BPHI & BPLO & BPHI & BPLO & BPHi & BPLO & BPHI & BPLO & BPHI & BPLO & BPHI & BPLO & BPHi \\
\hline Category & low & I high & $1 \mathrm{hr}(\mathrm{ppm})$ & $1 \mathrm{hr}(\mathrm{ppm})$ & $1 \mathrm{hr}(\mathrm{ppm})$ & $1 \mathrm{hr}(\mathrm{ppm})$ & $1 \mathrm{hr}(\mathrm{ppm})$ & $1 \mathrm{hr}(\mathrm{ppm})$ & 8-hrs(ppm) & 8-hrs(ppm) & 8-hr(ppm) & 8-hr(ppm) & $24 \mathrm{hr}\left(\mu \mathrm{g} / \mathrm{m}^{3}\right)$ & $24 \mathrm{hr}\left(\mu \mathrm{g} / \mathrm{m}^{3}\right)$ & $24 \mathrm{hr}\left(\mu \mathrm{g} / \mathrm{m}^{3}\right)$ & $24 \mathrm{hr}\left(\mu \mathrm{g} / \mathrm{m}^{3}\right)$ \\
\hline Good & 0 & 50 & 0 & 0.035 & 0 & 0.053 & None & None & 0 & 0.054 & 0 & 4.4 & 0 & 25 & 0 & 100 \\
\hline Acceptable & 51 & 100 & 0.036 & 0.075 & 0.054 & 0.1 & None & None & 0.055 & 0.07 & 4.5 & 9.4 & 25.1 & 75 & 100.1 & 350 \\
\hline Moderate & 101 & 150 & 0.076 & 0.185 & 0.101 & 0.36 & 0.125 & 0.164 & 0.071 & 0.085 & 9.5 & 12.4 & 75.1 & 100 & 350.1 & 400 \\
\hline Bad & 151 & 200 & 0.186 & 0.304 & 0.361 & 0.649 & 0.165 & 0.204 & 0.086 & 0.105 & 12.5 & 15.4 & 100.1 & 150.4 & 400.1 & 450 \\
\hline Very bad & 201 & 300 & 0.305 & 0.604 & 0.65 & 1.249 & 0.205 & 0.404 & 0.106 & 0.2 & 15.5 & 30.4 & 150.5 & 250.4 & 450.1 & 500 \\
\hline azardous & 301 & 500 & 0.605 & 1.004 & 1.25 & 2.049 & 0.405 & 0.604 & None & None & 30.5 & 50.4 & 250.5 & 500.4 & 500.1 & 700 \\
\hline
\end{tabular}

\section{Results and discussion}

From the calculation and data collection process, we mapped the monthly air quality over Kuwait to see the threshold of material over the air. Each of Figure showed the distribution of each pollutant. In Figure. 3, we can see that the distribution of $\mathrm{CO}$ over Kuwait shows the highest rate of $\mathrm{CO}$ over February before the pandemic and lockdown happened in Kuwait. Furthermore, the situation of the amount of $\mathrm{CO}$ was significantly reduced during the following months up to June 2020. The distribution of CO itself is almost the same over several districts in Kuwait. After the middle part of the year, the concentration of $\mathrm{CO}$ was increasing in some part of the urban area and continue to spread to all over the urban area around Kuwait up to the end of the year. 


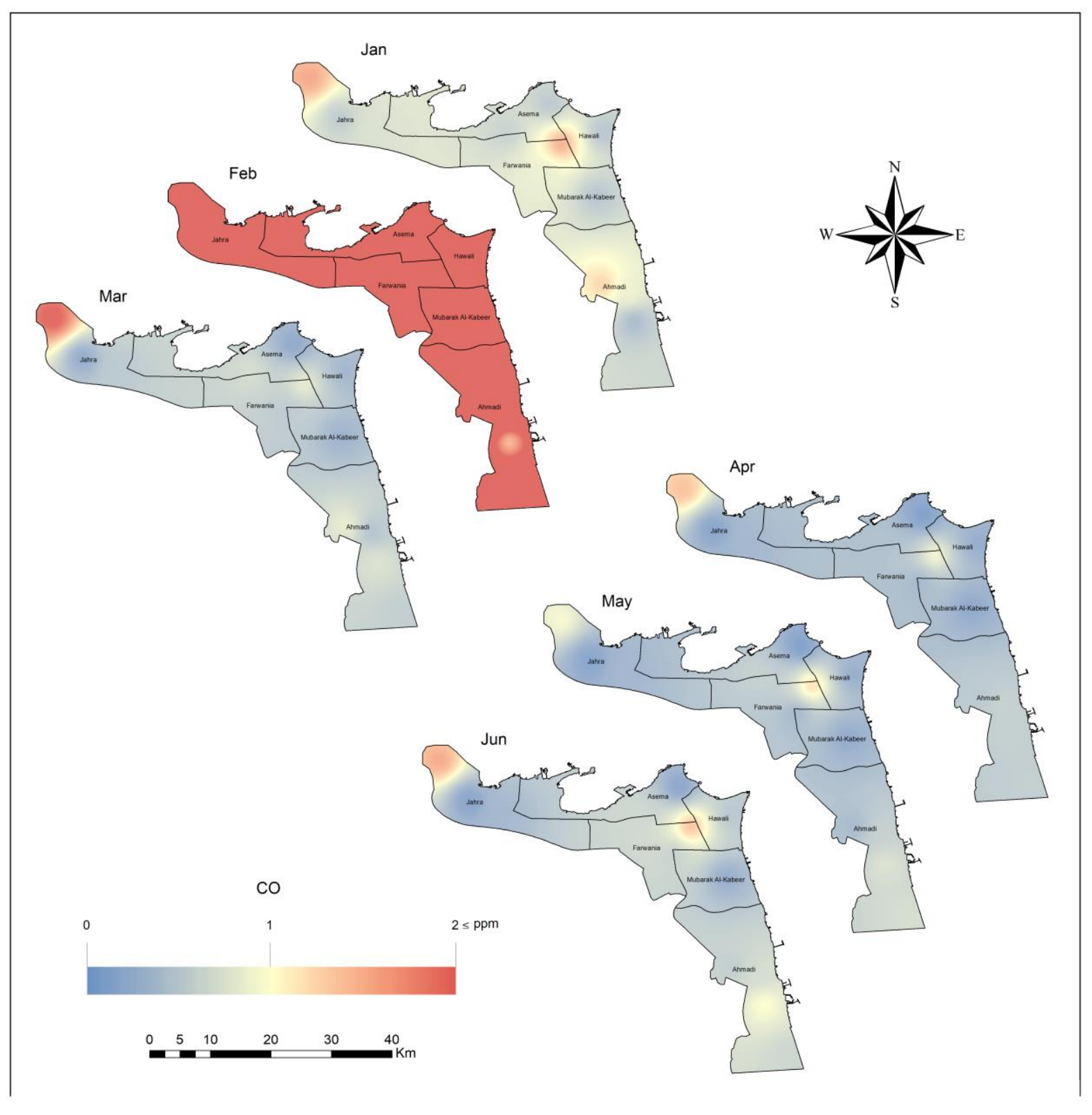




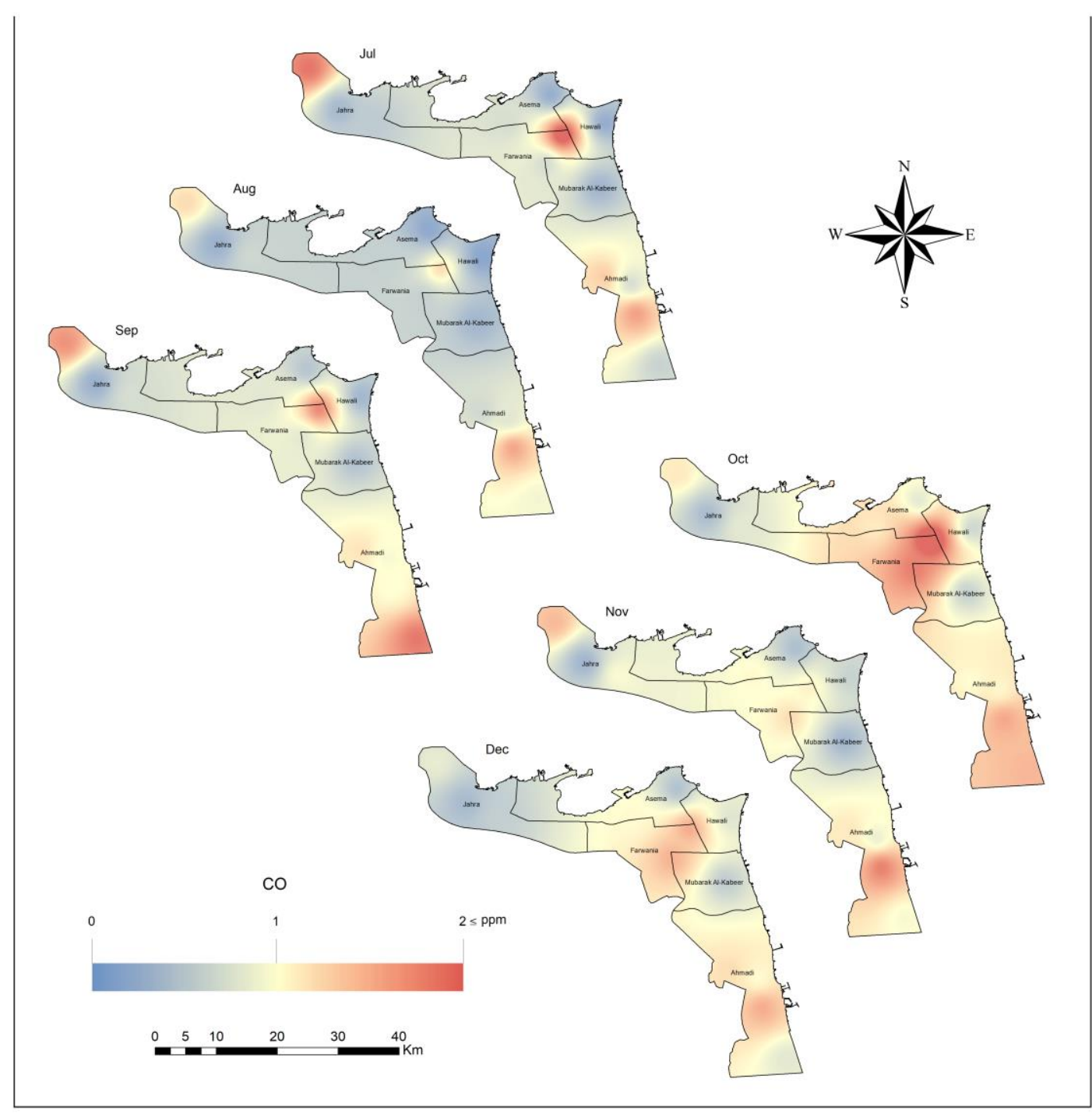

Fig. 3. The monthly geographical distribution of CO in 2020 in the State of Kuwait.

The average $\mathrm{NO}_{2}$ level measured in the morning, afternoon, and evening at the arrival terminal is $143.4 \mathrm{~g} / \mathrm{m} 3$, while the average $\mathrm{NO}_{2}$ level in the morning, afternoon, and evening at the departure terminal is $188.5 \mathrm{~g} / \mathrm{m} 3$. The $\mathrm{NO}_{2}$ level exceeds the quality standard according to National ambient air quality standard which is $92.5 \mathrm{~g} / \mathrm{m} 3$.

One of the sources of air pollution of $\mathrm{NO}_{2}$ gas comes from the transportation sector released by diesel-engine vehicles of $2.9 \%$ of the total sources of air pollution. The high levels of dust and $\mathrm{NO}_{2}$ in the morning and evening are caused by heavy bus traffic in the morning and evening. This happens because human activities begin in the morning and end in the afternoon, while during the day most people spend their time at work. This is also because the temperature difference is not much different with the wind speed is quite low and the weather is sunny from morning to evening. Low wind speed affects the levels of pollutants in the air collected in one place because there is no air dispersion, causing high levels of pollutants. The highest dust content is at the terminal arrival. This happens because the buses that come only drop off 
passengers and then enter and stop at the departure terminal so that the wind that carries dust from the ground, tire friction, and bus emissions becomes more than the buses at the departure terminal where most buses just stop to wait for the passengers. The number of buses waiting for passengers with the engine running causes more and more emission gases to be released and accumulated in the air, causing $\mathrm{NO}_{2}$ levels at the departure terminal to be higher than at the arrival terminal.

In Figure 4 we can see that the highest concentrate of $\mathrm{NO}_{2}$ happened in January where the human activity is still very high and the mobility with the vehicle are still considered to be active. The concentration was reduced by the time up to June, as the CO also decreasing from the air. This was happened while the human and mobility is also reducing due to the pandemic. Furthermore, the rate of $\mathrm{NO}_{2}$ were also increasingly high in the month of September where cancellation of the curfew imposed in all regions of the State of Kuwait from August 30, 2020, where anthropogenic activities started to return to normal including transportation.

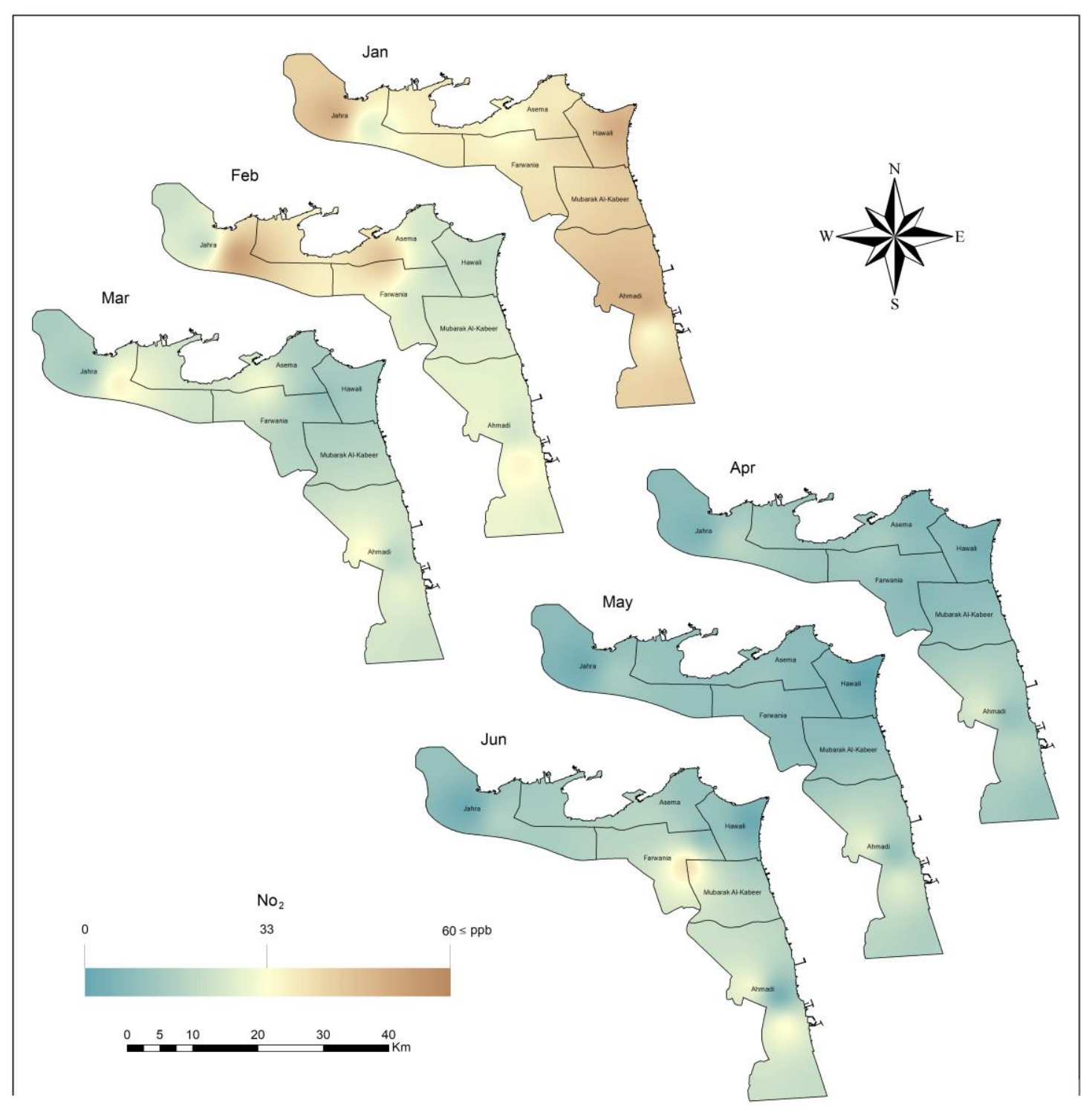




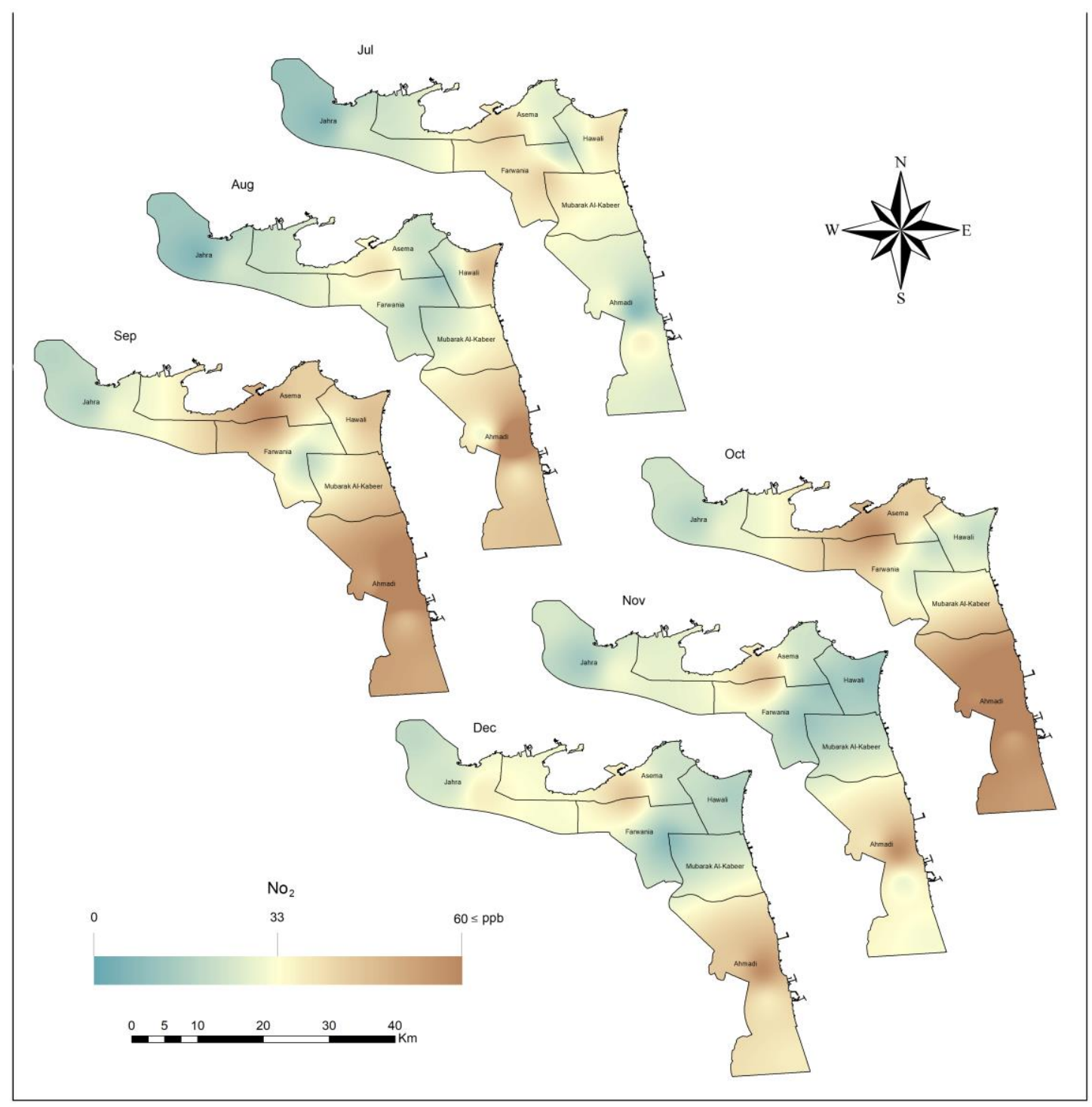

Fig. 4. The monthly geographical distribution of $\mathrm{NO}_{2}$ in 2020 in the State of Kuwait.

$\mathrm{NO}_{2}$ reduced during lockdown and curfew, and increased before pandemics precautions applied, and when lockdown cancelled, where it only showed the highest level in the months February and October with significantly high level in the area of Fahaheel, which is an industrial and urban area (Barkley et al., 2018), this is due to anthropogenic sources. Same as previous years, CO found to be high during February too (Abdul-Wahab et al., 2000) before precautions applied for the pandemic, then reduced due to decrease in anthropogenic sources when the curfew precautions and procedures started to applied, then started to increase again when the lockdown in some areas cancelled, and allowing taxis to work, allow governmental and private sectors to work less than $50 \%$ of the employees, allow visiting hotels and resorts, allow visiting social care homes. In previous years, both $\mathrm{NO}_{2}$ (Albassam et al., 2009) and CO (Albassam et al., 2009, Alhaddad et al., 2015) found to be at the highest levels due to traffic (Albassam et al., 2009, Alhaddad et al., 2015) and oil refineries activities (Alhaddad et al., 2015). $\mathrm{NO}_{2}$ levels also 
increased in previous years due to the emissions from power plant produced by air conditioning (Abdul-Wahab et al., 2000).

Not all parts of the refinery area have the potential to contain specific sources of exhaust gas in the form of Hydrogen Sulfide $\left(\mathrm{H}_{2} \mathrm{~S}\right)$. Based on data obtained from stations results and documentation, locations that have the potential for specific sources of $\mathrm{H}_{2} \mathrm{~S}$ gas are Shuwaick and Jahra. This where the map showed the concentration of the $\mathrm{H}_{2} \mathrm{~S}$ shows the highest concentration during the measurement. During the period January 2020-June 2020 the average wind speed is $2.38 \mathrm{~m} / \mathrm{s}$, while during the monitoring period from June to December 2020 the average wind speed is $2.38 \mathrm{~m} / \mathrm{s}$. - the average wind speed is $3.04 \mathrm{~m} / \mathrm{s}$. The trend of the cardinal directions moving to the northwest indicates that the $\mathrm{H}_{2} \mathrm{~S}$ gas is carried by the wind towards the northwest of the refinery. Therefore, it is necessary to pay more attention to environmental management in the surrounding area which is to the northwest of the refinery area, such as conducting routine monitoring and measurements to determine and ensure that the hydrogen sulfide concentration in the surrounding environment does not exceed the Threshold Value. Figure 5 showed that the concentration of $\mathrm{H}_{2} \mathrm{~S}$ is relatively stable in certain area.

Figure 5 showed that the concentration of $\mathrm{H} 2 \mathrm{~S}$ is relatively stable in certain area where the activity of oil and well completion happened in this area. The highest concentration of $\mathrm{H} 2 \mathrm{~S}$ can be seen in June 2020 where the activity of oil has been increasingly active and massive. The H 2 S concentration has nearby the area of A and B and spread with low concentration over the surrounding area itself.

These established standards are prepared and used in general. Continuous exposure to $\mathrm{H}_{2} \mathrm{~S}$ has the potential to cause health problems. In addition to affecting and causing danger to human health, $\mathrm{H}_{2} \mathrm{~S}$ also affects metal equipment because $\mathrm{H}_{2} \mathrm{~S}$ is corrosive to metals. In practice, for oil and gas sector activities, these conditions can occur in pipelines or in metal tanks, so special handling is needed to avoid corrosion which will result in cracks or leaks. In addition, $\mathrm{H}_{2} \mathrm{~S}$ will also cause ferrous sulfide (FeS) to rust on ferrous metals. The FeS is pyrophoric, which when reacts with oxygen in the air will produce heat. $\mathrm{H}_{2} \mathrm{~S}$ where increased due to oil refineries activities, before the pandemic, the levels of this pollutant are high in urban areas near petroleum activities (Al-Salem and Khan, 2008) 


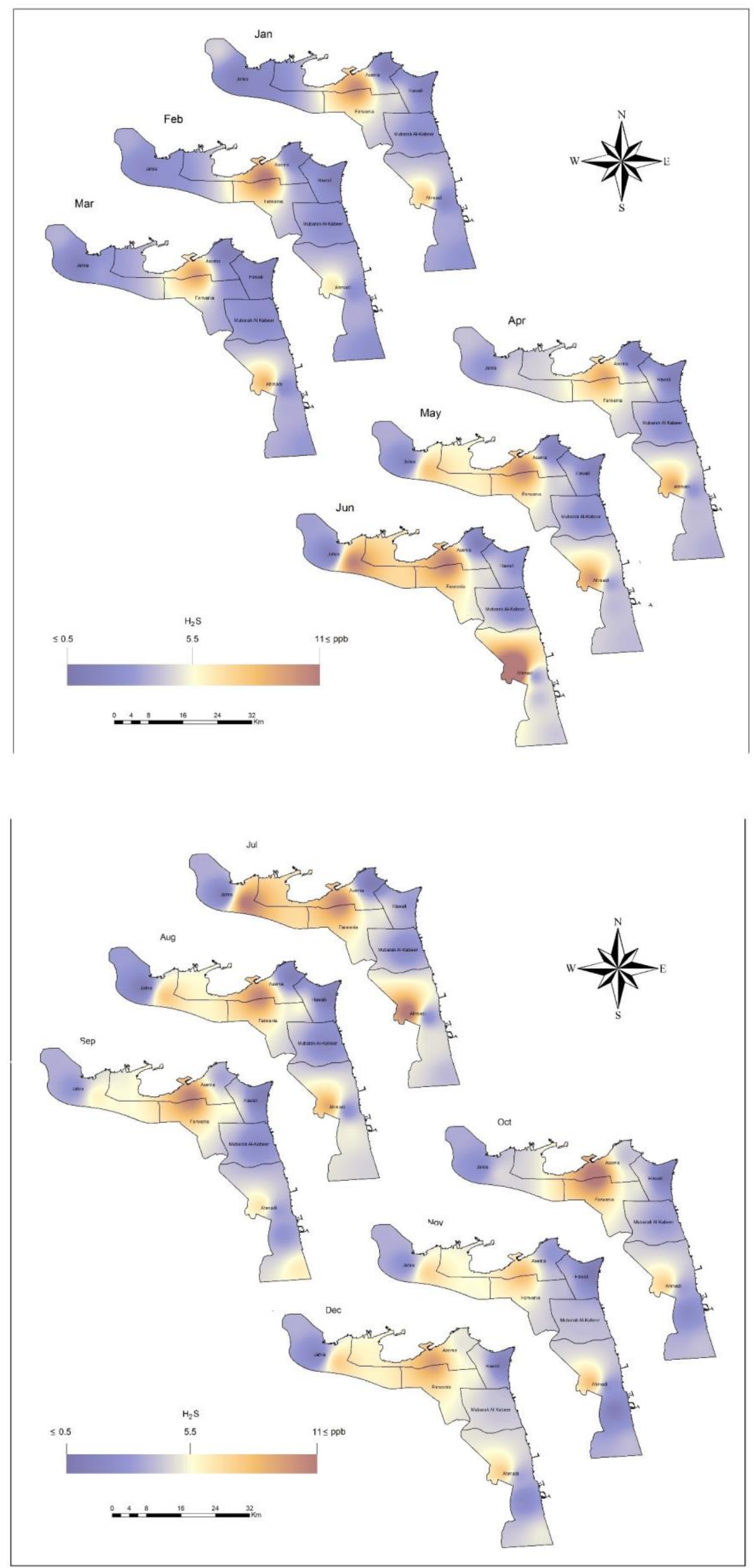

Fig. 5. The monthly geographical distribution of $\mathrm{H}_{2} \mathrm{~S}$ in 2020 in the State of Kuwait. 
Based on Fig 6 we can see that the concentration of $\mathrm{O}_{3}$ is still considered as low in the month of January 2020. This can be seen that in January 2020 the concentration of $\mathrm{O}_{3}$ is no more than $20 \mathrm{ppm}$ in all over the area. But this condition was changed as the time up to June 2020 where the concentration of $\mathrm{O}_{3}$ in some area can reach in to the maximum number of $40 \mathrm{ppm}$ in some area in the north, while the area in the south has not significantly increasing and still around the number below 25ppm. The condition of the 3 concentration has changed from July to Dec 2020 where the $\mathrm{O}_{3}$ concentration has also decreasing and showed the lowest value again in December 2020. This may happen as the temperature and the weather in Kuwait City has changed all over the year and affects the concentration number of $\mathrm{O}_{3}$.

$\mathrm{O}_{3}$ concentrations fluctuated between showed decrease in summer, where it used to be high during this time in previous years (Abdul-Wahab et al., 2000, Al-Rashidi et al., 2018, Yassin et al., 2018), this is show that decrease in traffic has a significant effect in decreasing the Ozon.

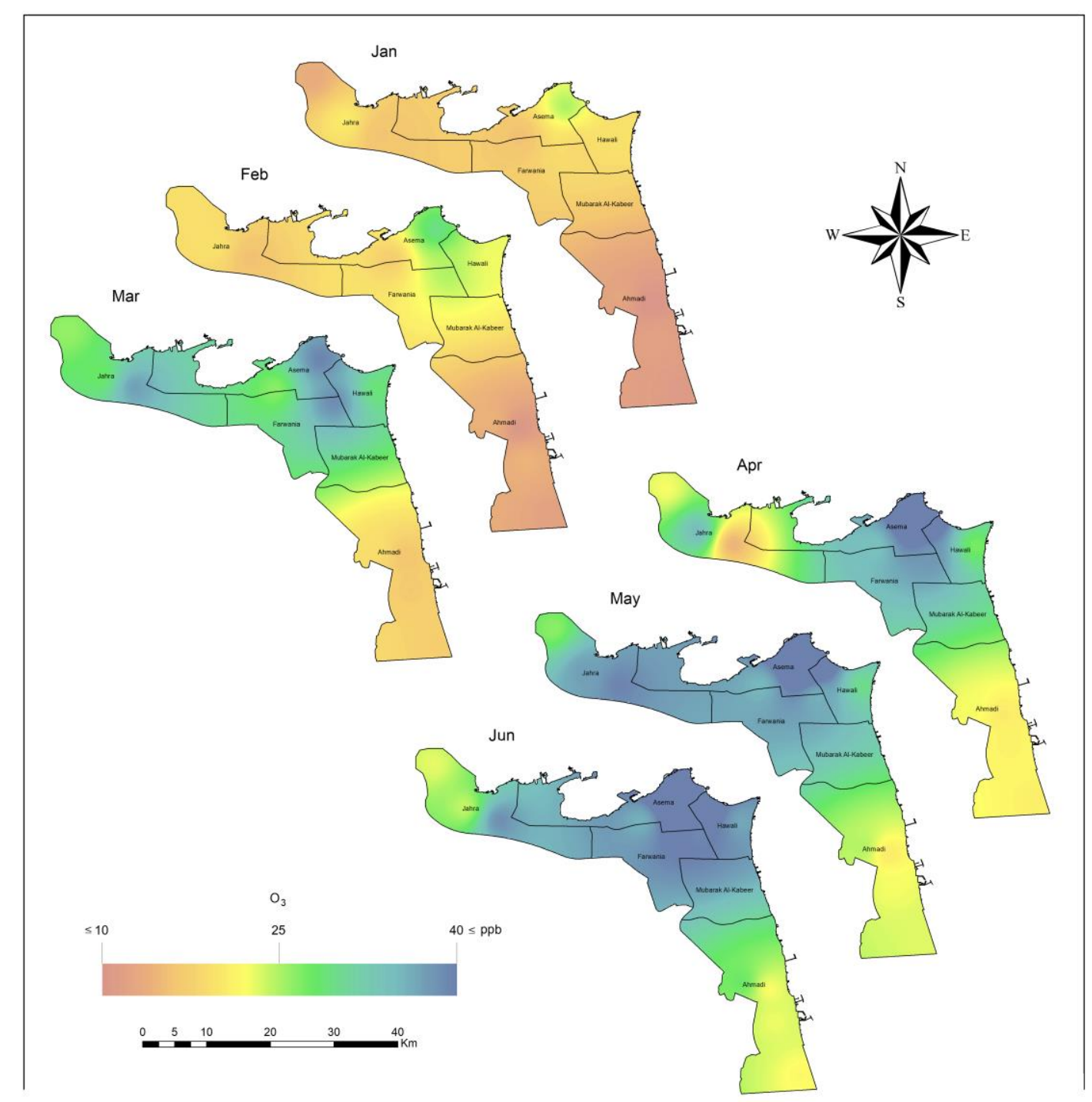




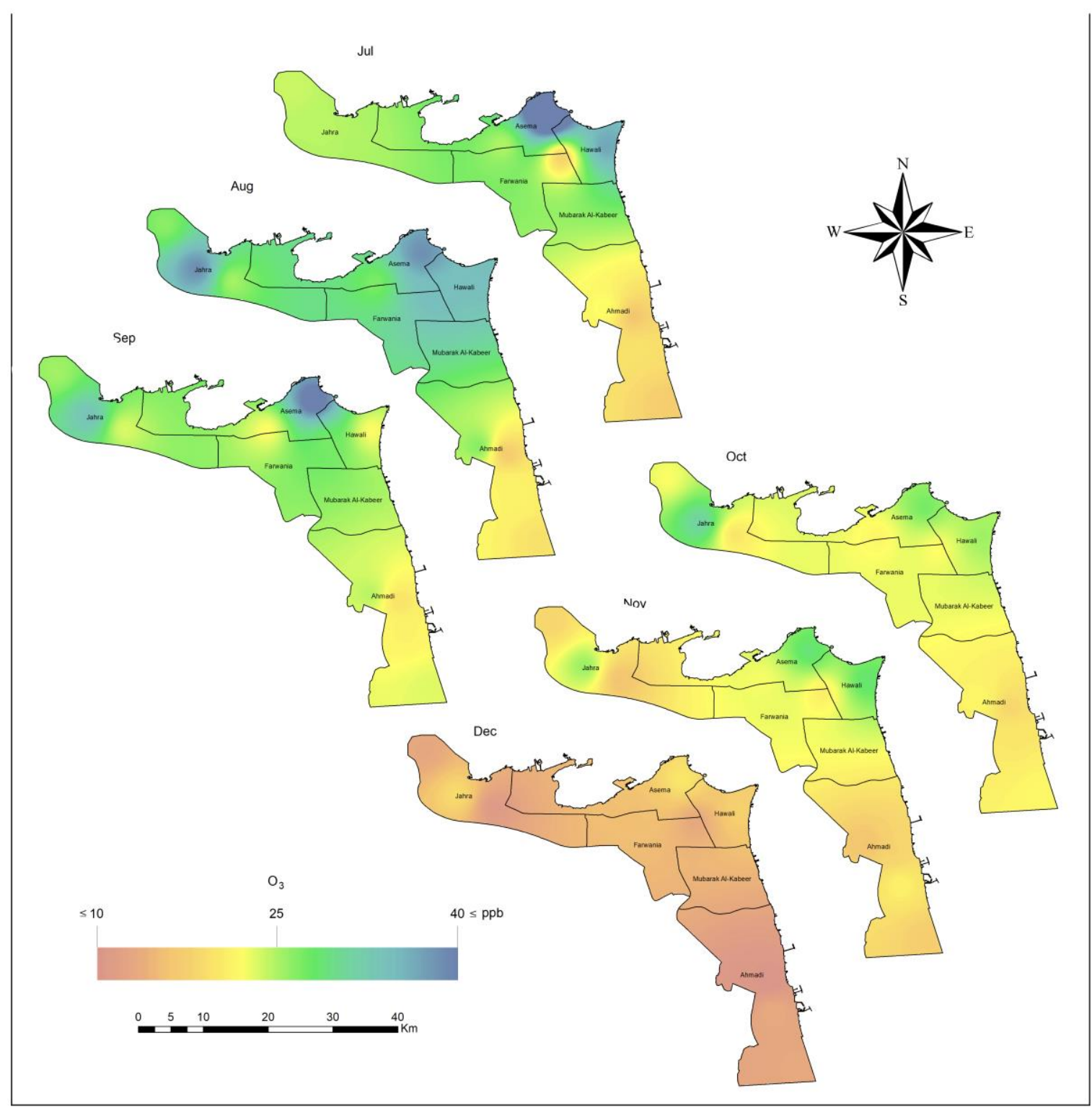

Fig. 6. The monthly geographical distribution of $\mathrm{O}_{3}$ in 2020 in the State of Kuwait.

The statistical results for sulfur dioxide $\left(\mathrm{SO}_{2}\right)$ showed that there was a significant relationship between sulfur dioxide $\left(\mathrm{SO}_{2}\right)$ and the number of ARI cases $(\mathrm{p}=0.046) . \mathrm{SO}_{2}$ in the air is mostly produced by burning forests, transportation fuels. $\mathrm{SO}_{2}$ will remain in the air with a small concentration of water vapor, but if there is enough water vapor in the air it will react with $\mathrm{SO}_{2}$ to become $\mathrm{H}_{2} \mathrm{SO}_{4}$ which will cause interference with the mucous membranes of the nose, throat, respiratory tract and eventually reach the lungs. Sulfur dioxide $\left(\mathrm{SO}_{2}\right)$ comes from human activities can come from economic activities and transportation.

From Fig 7 we can see that the lowest concentration of $\mathrm{SO}_{2}$ in Kuwait is on November 2020 where the weather is relatively cold. The high concentration of $\mathrm{SO}_{2}$ is only happening in some area where the centre of human activity happening especially in month of June, Sep, and Oct. 

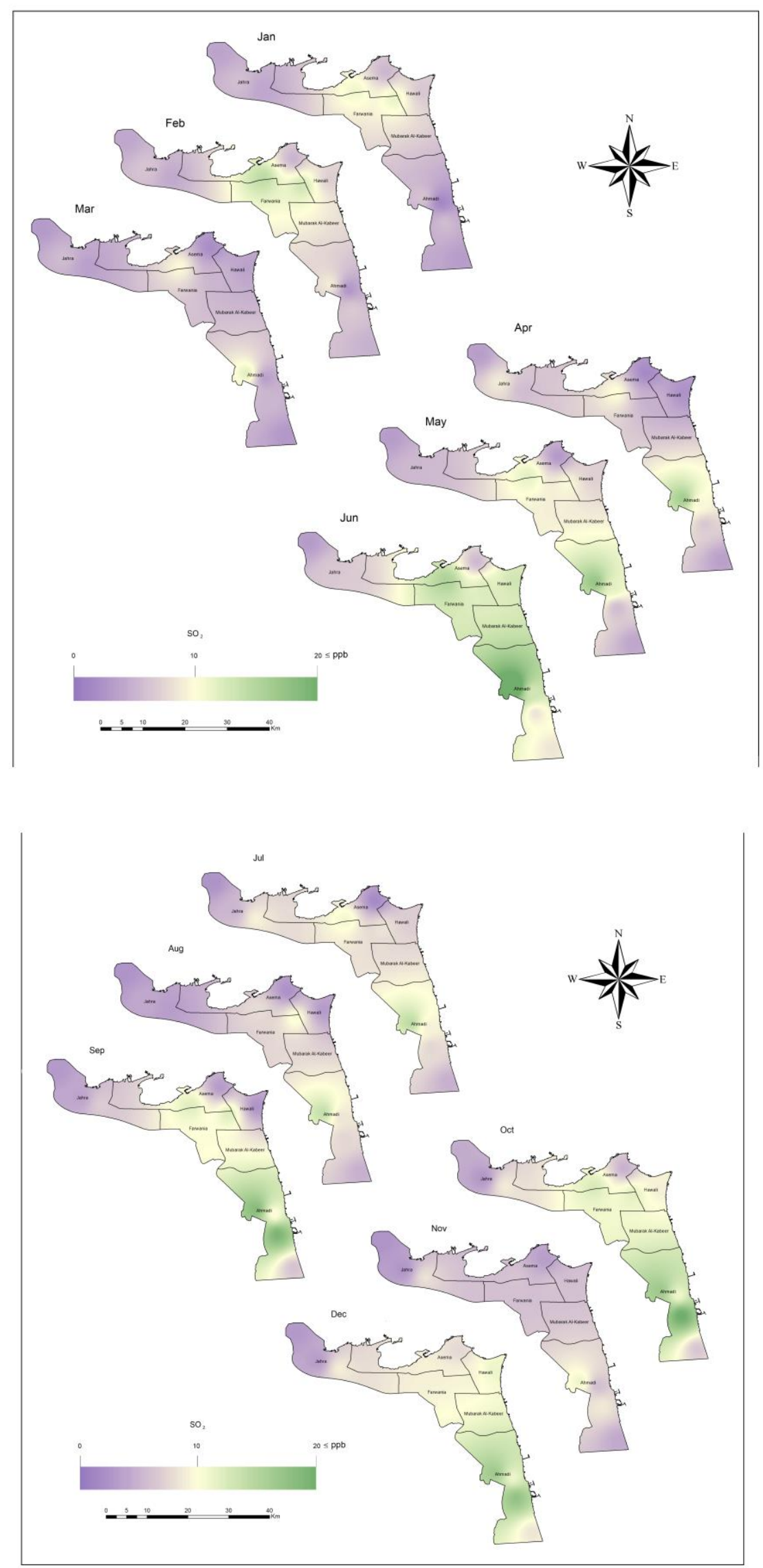

Fig. 7. The monthly geographical distribution of $\mathrm{SO}_{2}$ in 2020 in the State of Kuwait. 
$\mathrm{SO}_{2}$ found to be low in November due to decrease in temperature, and found to be high in some areas especially in June, September, and October, due to anthropogenic activities, where curfew hours decreased, and then cancelled in all Kuwait for partial returning to normal life. This is proved that the high levels of $\mathrm{SO}_{2}$ earlier years were due to increase of population, traffic, power plants work, and industrial activities (Al-Baroud et al., 2017), where in the previous years it's used to be found in high concentrations in residential areas exceeding the guidelines limits (AlAwadhi and Yassin, 2010), and especially in summer from the emissions produced from excessive use of air conditioning in power plants (Abdul-Wahab et al., 2000).

The concentration of P.M $\mathrm{M}_{2.5}$ over the air in Kuwait City showed the highest part in the area of Jahra and showed significantly high concentrate in the month of Feb, April, June, Aug, Sep, Nov, and Dec while in the other area the concentration is not significantly high and only show medium rate of concentration in east part of Kuwait showed relatively low concentrate of this particle in the month of Jan-Mar and May while the area in the north is relatively high all over the year (Fig. 8). $\mathrm{PM}_{2.5}$ found to be low from January to March, and May, due to decrease in anthropogenic activities as a result of lockdown and curfew.

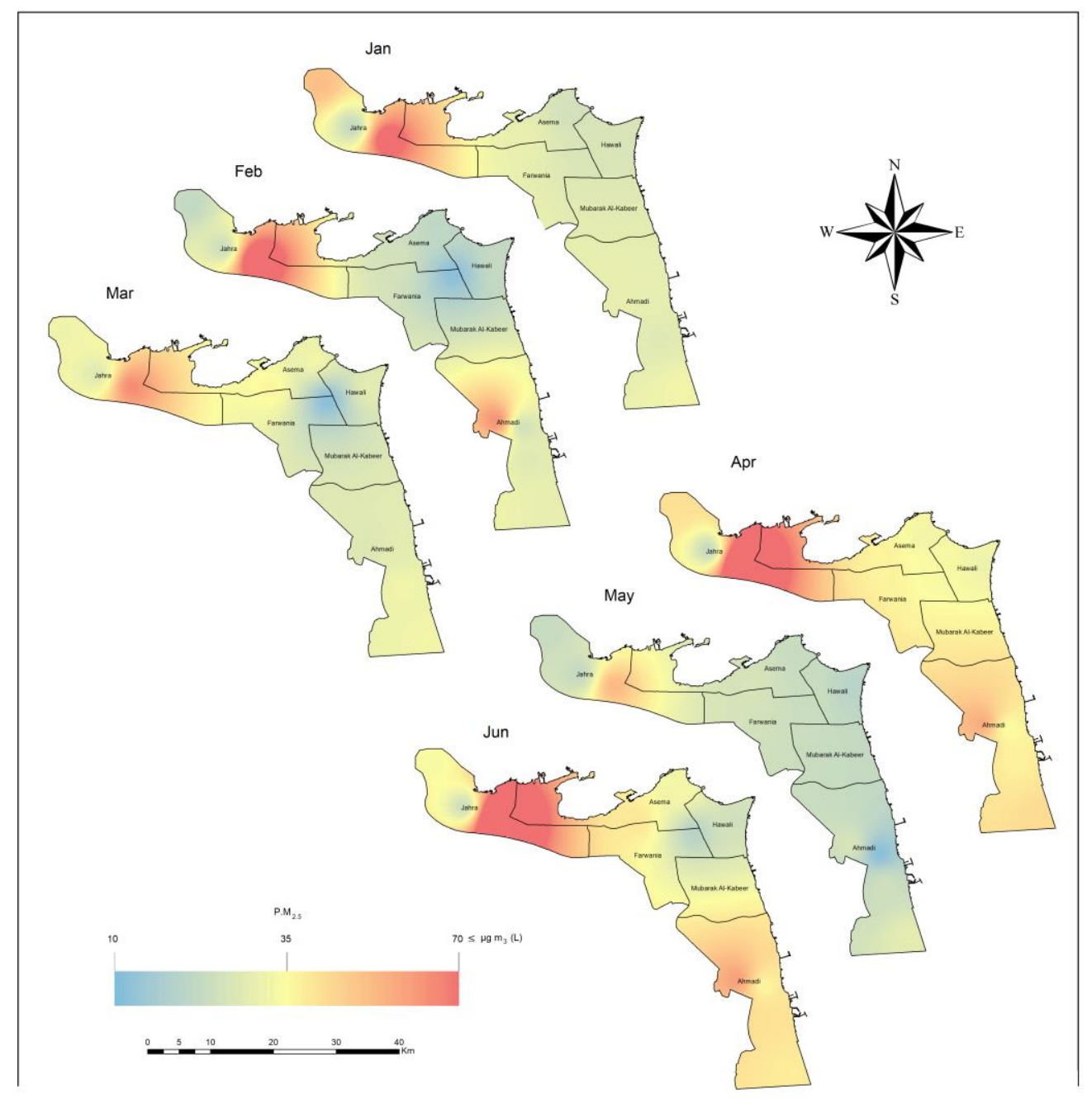




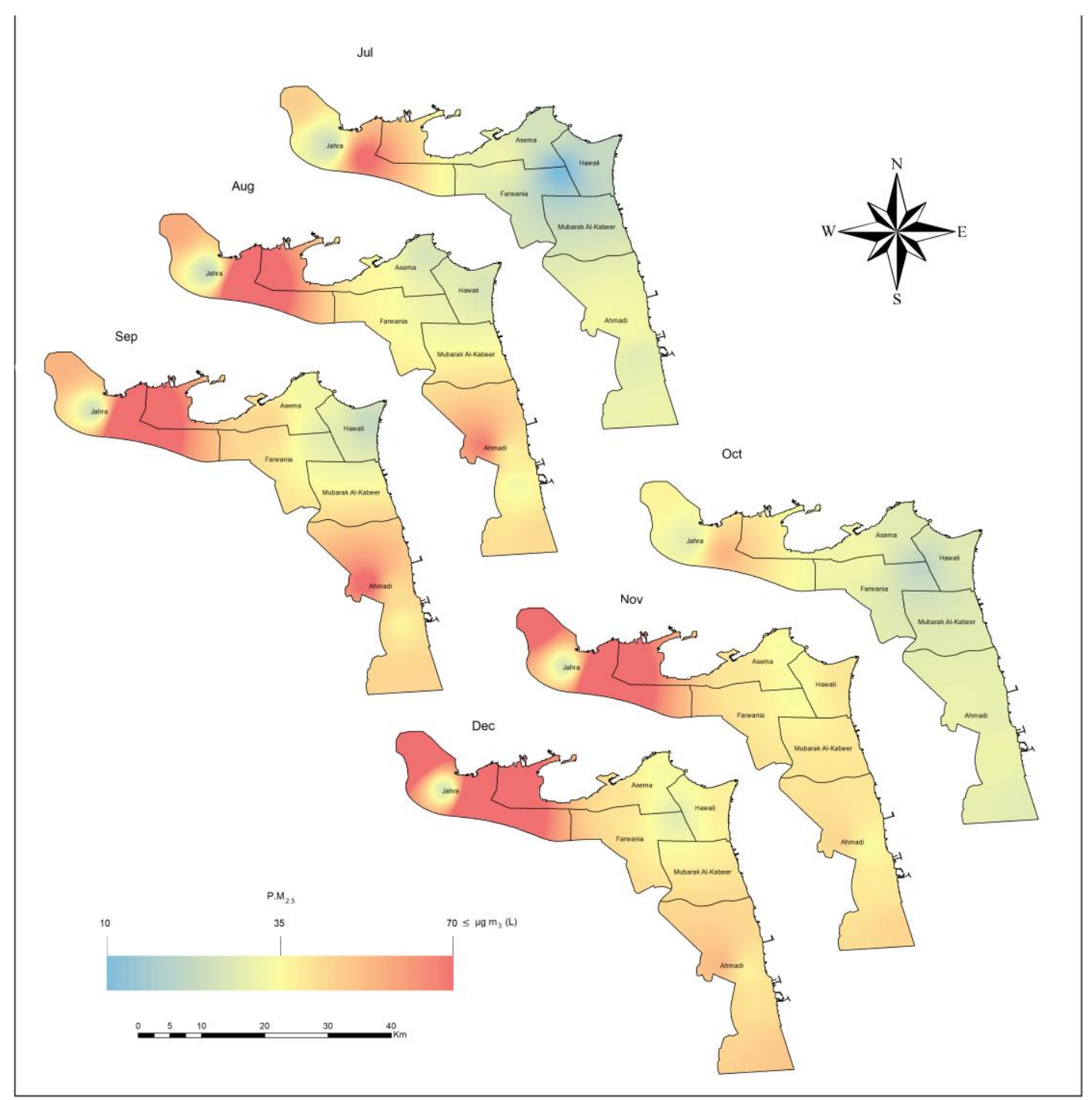

Fig. 8. The monthly geographical distribution of $\mathrm{PM}_{2.5}$ in 2020 in the State of Kuwait.

$\mathrm{PM}_{10}$ concentrate showed the lowest concentration in the month of February and quite stabilize in the month of November (Fig. 9). PM $_{10}$ found to be at its lowest during February, this is a result from the curfew and banning celebration during National Day and Liberation Day of Kuwait, which decreased anthropogenic activities, where in previous years it used to exceed the Kuwait EPA guidelines (Al-Hurban et al., 2021). 

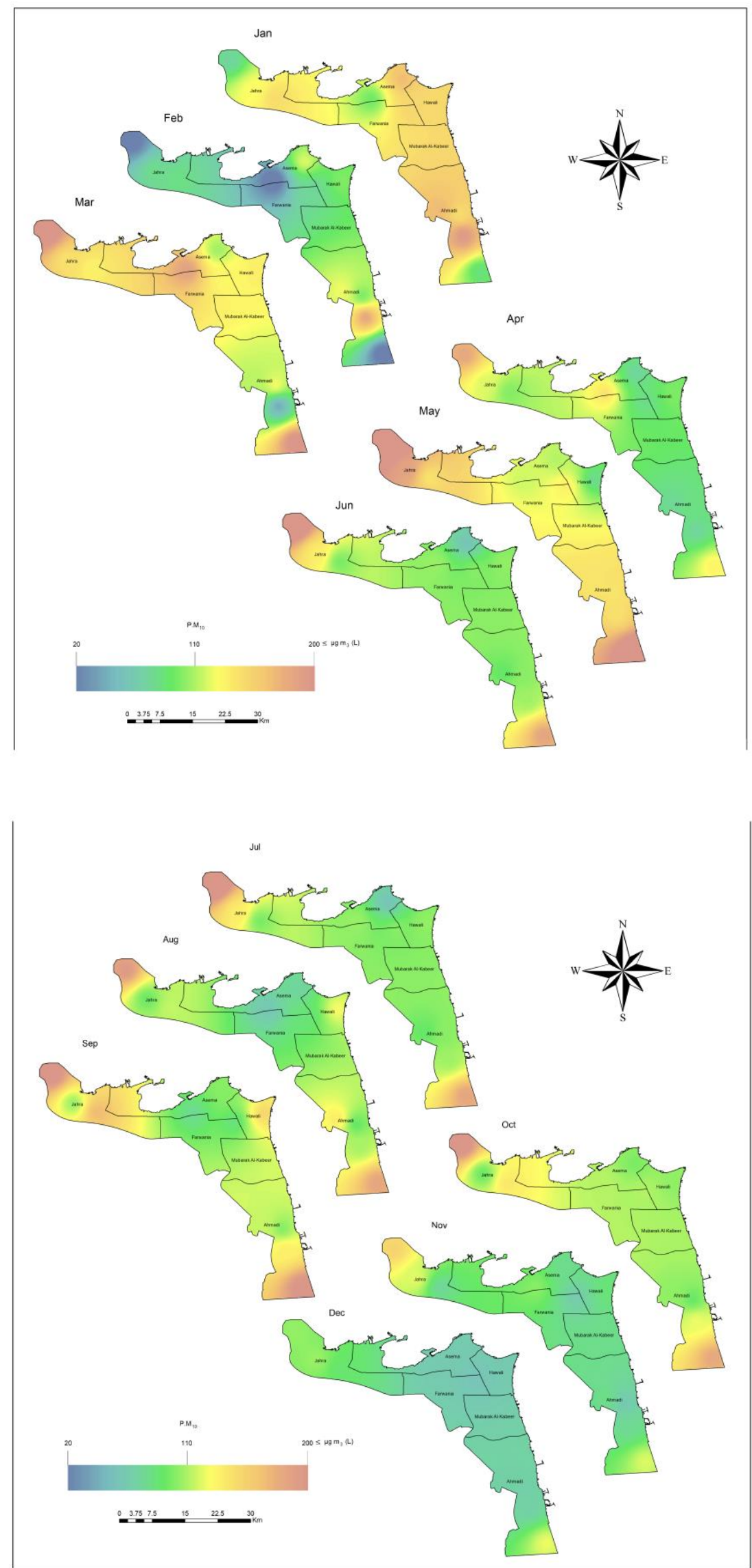

Fig. 9. The monthly geographical distribution of $\mathrm{PM}_{10}$ in 2020 in the State of Kuwait. 
in Fig. 10 we can see that the concentration of $\mathrm{CO}$ showed the highest rate all over the area in the month of February. While the concentration of $\mathrm{H}_{2} \mathrm{~S}$ shows relatively dynamic and different in every area, but the highest rate showed in the month of June where the area of Ahmadi, Shuwaikh and Saad Al-Abdullah. The concentration of $\mathrm{NO}_{2}$ showed the highest rate in the month of February and October and showed the significantly high in the area of Fahaheel when it reached $96.39 \mathrm{ppm}$. The rate of $\mathrm{O}_{3}$ is also dynamic and different for each of area but showed the highest rate of concentration in the month of June when it reached 63.1 in the area of Mansouria. Furthermore, the concentration of $\mathrm{SO}_{2}$ also showed the dynamic value over the time and showed the highest peak of concentration in the month of June in the area of Ahmadi.
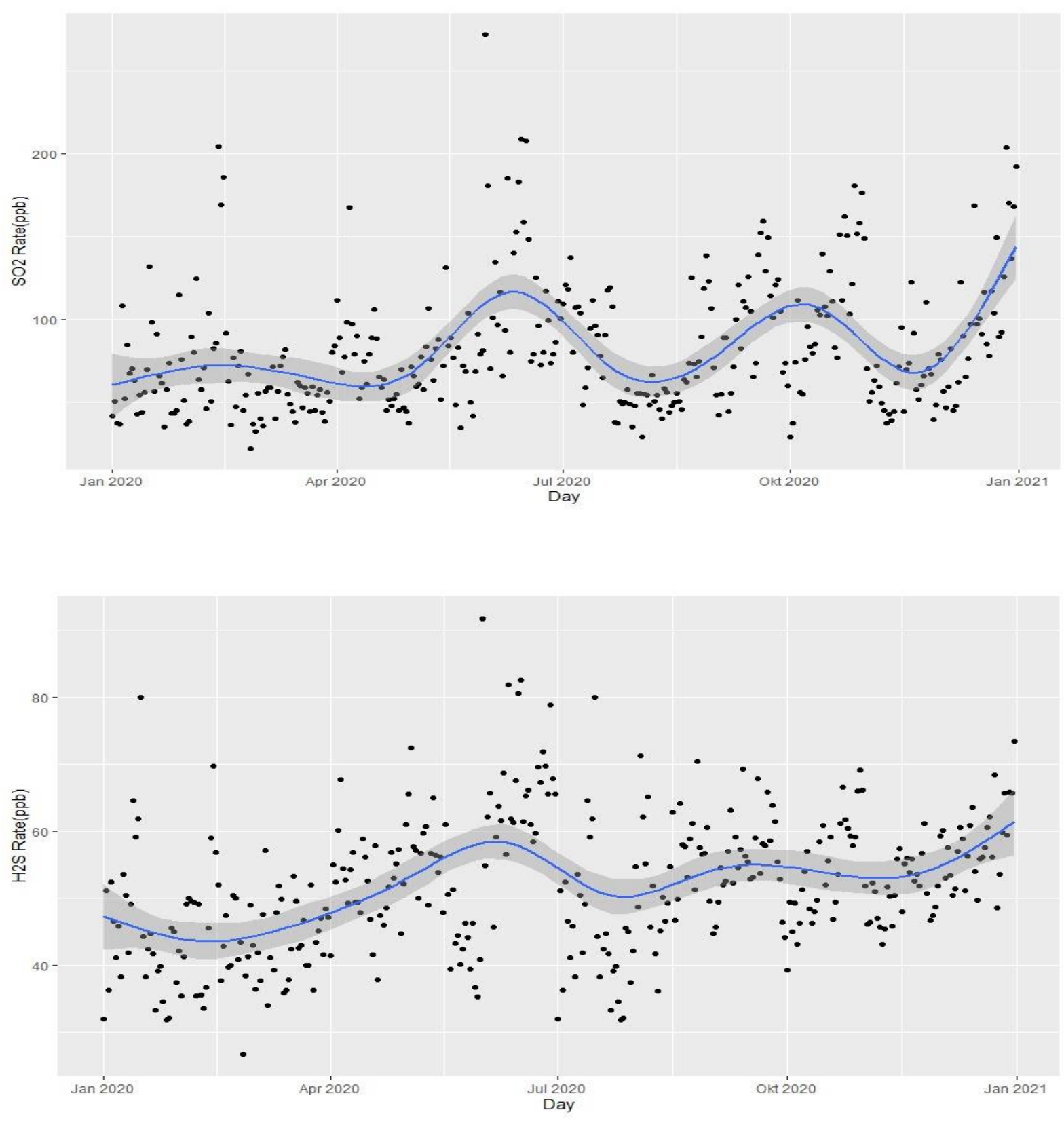

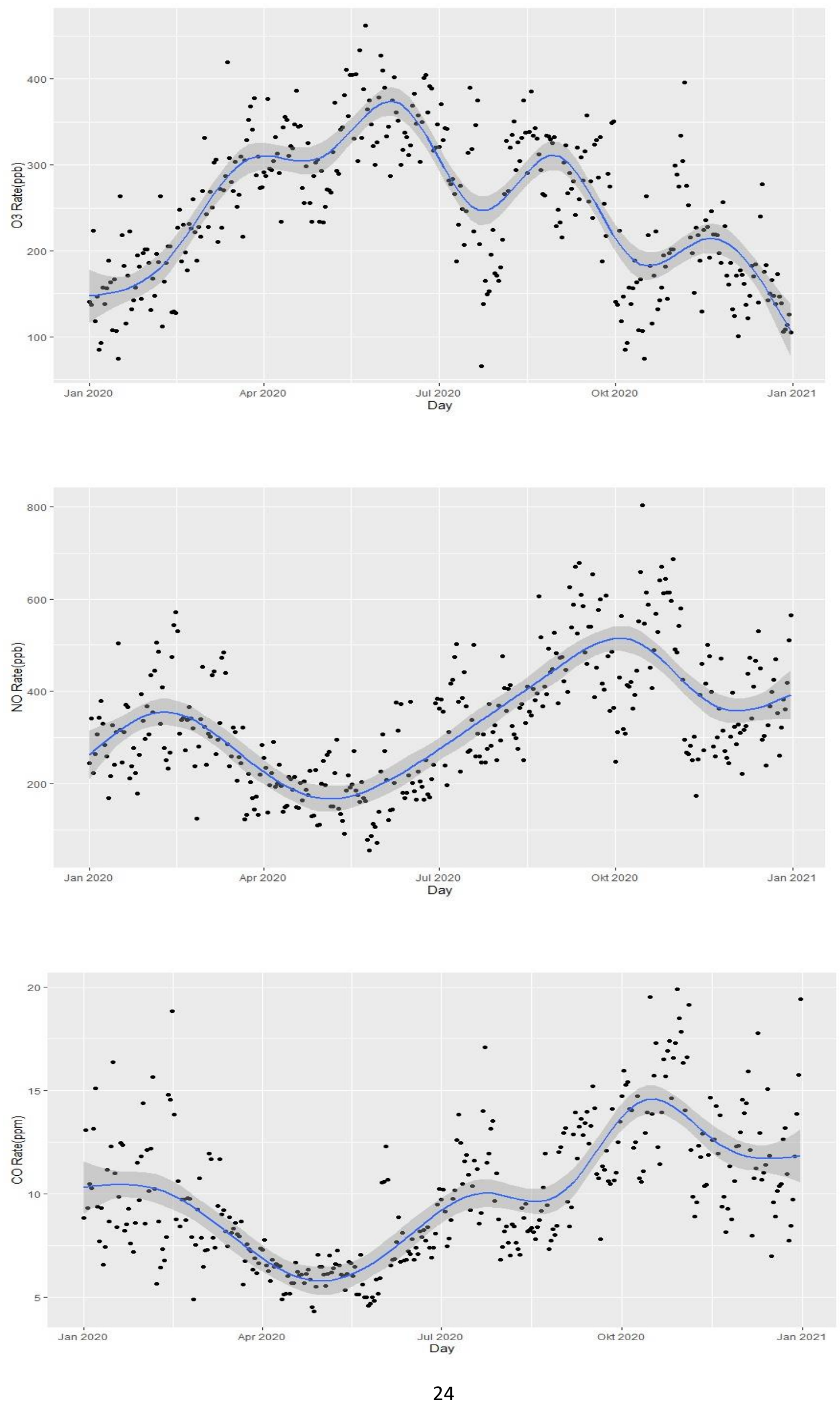

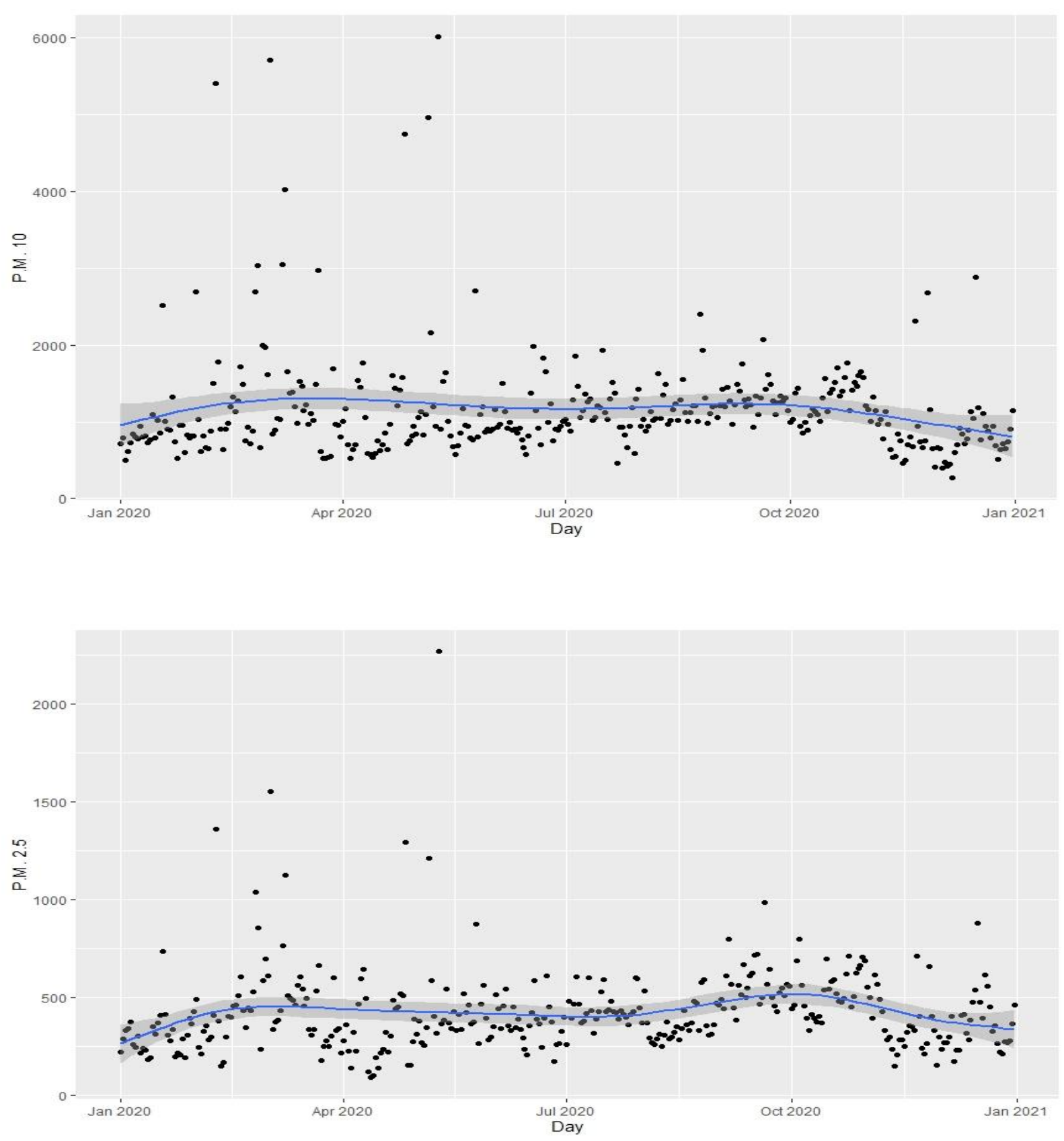

Fig. 10. The temporal distribution of the studied gases in the State of Kuwait over 2020.

$\mathrm{SO}_{2}$ appearance every year show that the peak of occurrence in Kuwait was happened in June and October. The rate also shows that the occurrence of $\mathrm{SO}_{2}$ increasing in the end and the beginning of next year. $\mathrm{H}_{2} \mathrm{~S}$ show the increasing trend along the year and also keep increasing to the beginning of next year. The occurrence of $\mathrm{O}_{3}$ show the peak on June 2020 and decreasing in another month. This happened during six months of 2020 while in the beginning of the year it shows the increasing pattern. The appearance of $\mathrm{O}_{3}$ seems to get back to its beginning value on the end of the year. NO seems to have the increasing pattern during the year of 2020. CO also has increasing pattern on the year of 2020 and show the highest value on November 2020 while the lowest point occurrence was on May 2020 when the lock down begins. The P.M $\mathrm{M}_{10}$ 
shows 5 outliers during year of 2020 and show stable form from the beginning of the year. The P.M $\mathrm{M}_{2.5}$ shows slightly increasing patter.

Table. 5. Analysing the air quality index in Kuwait based on the monthly averages of the six

\begin{tabular}{|l|r|r|r|r|r|r|r|r|r|r|r|r|}
\hline & 1 & 2 & 3 & 4 & 5 & 6 & 7 & 8 & 9 & 10 & 11 & 12 \\
\hline $\mathrm{CO}$ & & & & & & & & & & & & \\
\hline $\mathrm{NO}_{2}$ & & & & & & & & & & & & \\
\hline $\mathrm{O}_{3}$ & & & & & & & & & & & & \\
\hline $\mathrm{P}_{2.5}$ & & & & & & & & & & & & \\
\hline $\mathrm{P}_{2 . M}$ & & & & & & & & & & & & \\
\hline $\mathrm{SO}_{2}$ & & & & & & & & & & & & \\
\hline
\end{tabular}

studied gases.

\section{Good Acceptable Moderate Bad Very Bad Hazardous}

After the calculation and mapping progress we can see from Table 5 that the concentration of air pollution in Kuwait based on the averages, the rate is still considered as GOOD and shows relatively same in each of the month. But the concentration of P.M 2.5 showed acceptable rate in the whole year and the concentration of $\mathrm{P}_{10} \mathrm{M}_{10}$ showed GOOD condition in the month of January, November and December while showed the rate of acceptable in the rest of the months.

\section{Conclusion}

This paper concludes that during COVID-19 in the year 2020 concentrations of all the pollutants except $\mathrm{PM}_{2.5}$ were decreased when the precautions applied during the pandemic as a result of the decrease in anthropogenic activities, however, for the pollutants $\mathrm{PM}_{2.5}$ data showed an increase in concentrations. Mostly because of the transported dust. This paper prove that anthropogenic activities contribute to the increase of most of air pollutants, hence new regulations and laws should set to limit and control these activities to reduce and control the increase for air pollution, which in turn will reduce health problems, have more clean air quality, and decrease the financial burden on several sectors in the country including medical sectors. We recommend to apply some laws from the precautions applied during the pandemic such as working from home, and shorten working hours for some jobs, decrease non-necessary expats numbers. This study presents a spatio-statistical methodology that can be followed to study the impact of policies adopted to confront the Covid-19 epidemic on air quality. 


\section{Funding}

This research received no specific grant from any funding agency in the public, commercial, or not-for-profit sectors.

\section{Competing interests}

The authors declare no competing interests.

\section{ACKNOWLEDGMENTS}

The authors would like to thank the Environmental Public Authority (KEPA). Especially, eMISK, air quality monitoring department. Also, acknowledgments must go to Mr. Sherif AlKhayat, the Director of the Air Quality Monitoring Department in KEPA for the enriching discussion about air quality in Kuwait.

\section{References}

Abdul-Wahab, S., Bouhamra, W., Ettouney, H., Sowerby, B. \& Crittenden, B. D. 2000. Analysis of air pollution at Shuaiba Industrial Area in Kuwait.

Adamkiewicz, G., Ebelt, S., Syring, M., Slater, J., Speizer, F., Schwartz, J., Suh, H. \& Gold, D. 2004. Association between air pollution exposure and exhaled nitric oxide in an elderly population. Thorax, 59, 204-9.

Al-Awadhi, M. \& Yassin, M. 2010. Evaluating the impacts of SO 2 emissions from power stations in Kuwait.

Al-Hemoud, A., Al-Dousari, A., Al-Shatti, A., Al-Khayat, A., Behbehani, W., \& Malak, M. 2018. Health Impact Assessment Associated with Exposure to PM10 and Dust Storms in Kuwait. Atmosphere, 9(1). https://doi.org/10.3390/atmos9010006

Albanai, J. A. 2019. A GIS Science Simulation for the Expected Sea Level Rise Scenarios on Failka Island in The State of Kuwait (1st ed.). Kuwait: Center For Research and Studies on Kuwait.

Albanai, J. A. 2021a. Mapping Kuwait bathymetry using passive multispectral remote sensing. Kuwait Journal of Science, 48(4), 1-10. doi.org/10.48129/kjs.v48i4.8978.

Albanai, J. A. 2021b. Seasonal Spatial and Temporal Distribution of Chlorophyll-a Concentration over Kuwait and the Arabian Gulf using Satellite and In-Situ Data (Issue July). https://doi.org/10.20944/preprints202107.0232.v1

Albanai, J. A. 2020. Sea Level Rise Projections for Failaka Island in The State of Kuwait. Transactions on Maritime Science, 9(2), 236-247. https://doi.org/10.7225/toms.v09.n02.008. 
Alkhalidi, M. A., Al-Dabbous, S. K., Neelamani, S., \& Aldashti, H. A. 2019. Wind energy potential at coastal and offshore locations in the state of Kuwait. Renewable Energy, 135, 529-539. https://doi.org/https://doi.org/10.1016/j.renene.2018.12.039

Al-Baroud, A., Al-Baroud, F., Al-Sahali, M. \& Ettouney, H. 2017. Annual variations of air pollution in Jahra, Kuwait.

Albassam, E., Khan, A. \& Popov, V. 2009. Management of air quality in the vicinity of congested area in Kuwait. Environ Monit Assess, 157, 539-55.

Alhaddad, A., Ettouney, H. \& Saqer, S. 2015. Analysis of air pollution emission patterns in the vicinity of oil refineries in Kuwait.

Alhajeri, N. S., Al-Fadhli, F. M. \& Aly, A. Z. 2019. Unit-Based Emissions Inventory for Electric Power Systems in Kuwait: Current Status and Future Predictions. Multidisciplinary Digital Publishing Institute.

Al-Hemoud, A., Gasana, J., Al-Dabbous, A., Alajeel, A., Al-Shatti, A., Behbehani, W. \& Malak, M. 2019. Exposure levels of air pollution $\left(\mathrm{PM}_{2.5}\right)$ and associated health risk in Kuwait. Environ Res, 179, 108730.

Al-Hurban, A., Khader, S., Alsaber, A. \& Pan, J. 2021. Air Quality Assessment in the State of Kuwait during 2012 to 2017. Atmosphere, 12, 678.

Aljahdali, M.O., Alhassan, A.B., Albeladi, M.N., 2021. Impact of novel coronavirus disease (COVID-19) lockdown on ambient air quality of Saudi Arabia. Saudi J. Biol. Sci. 28, 1356-1364. doi:10.1016/j.sjbs.2020.11.065

Alolayan, M., Brown, K., Evans, J., Bouhamra, W. \& Koutrakis, P. 2012. Source apportionment of fine particles in Kuwait City. The Science of the total environment, 448.

Alomair, O., Alenezy, T. \& Hamed, M. 2013. Assessment of Ambient Air Quality in the State of Kuwait: Al Jahra City Study.

Al-Rashidi, M., Yassin, M., Alhajeri, N. \& Malek, M. 2018. Gaseous air pollution background estimation in urban, suburban, and rural environments. Arabian Journal of Geosciences, 11.

Alsaber, A., Pan, J., Alkandary, D., Al-Hurban, A., Setiya, P., Group, K., Saleh, K., Al-Awadhi, A., Al-Kandari, W., Hasan, E., Ghanem, A., Hussain, M., Ali, Y., Nahar, E., Alenizi, A., Hayat, S., Abutiban, F., Aldei, A., Alhajeri, H. \& Al-Herz, A. 2020. Influence of Ambient Air Pollution on Rheumatoid Arthritis Disease Activity Score Index. International Journal of Environmental Research and Public Health, 17.

Al-Salem, S. \& Khan, A. 2008. Comparative assessment of ambient air quality in two urban areas adjacent to petroleum downstream/upstream facilities in Kuwait. Brazilian Journal of Chemical Engineering - BRAZ J CHEM ENG, 25.

Anil, I., Alagha, O., 2021. The impact of COVID-19 lockdown on the air quality of Eastern 
Province, Saudi Arabia. Air Qual. Atmos. Health 14, 117-128. doi:10.1007/s11869-02000918-3.

Arif, M., Kumar, R., Parveen, S., Singh, K. \& Singh, J. 2021. Reduction in Environmental Pollution Due to Lockdown in the COVID-19 Pandemic.

Barkley, M. P., González Abad, G., Kurosu, T. P., Spurr, R., Torbatian, S. \& Lerot, C. 2018. OMI air-quality monitoring over the Middle East.

Broomandi, P., Karaca, F., Nikfal, A., Jahanbakhshi, A., Tamjidi, M., Kim, J.R., 2020. Impact of COVID-19 event on the air quality in Iran. Aerosol Air Qual. Res. 20, 17931804. doi:10.4209/aaqr.2020.05.0205.

Brown, K., Bouhamra, W., Lamoureux, D., Evans, J. \& Koutrakis, P. 2008. Characterization of Particulate Matter for Three Sites in Kuwait. Journal of the Air \& Waste Management Association, 58, 994-1003.

Cascella, M. Rajnik, M. Cuomo, A. Dulebohn, S.C. Di Napoli, R. 2020. Features, Evaluation and Treatment Coronavirus (COVID-19). Treasure Island, FL, USA: StatPearls Publishing LLC.

Chaplot, V., Darboux, F., Bourennane, H., Leguédois, S., Silvera, N., \& Phachomphon, K. 2006. Accuracy of interpolation techniques for the derivation of digital elevation models in relation to landform types and data density. Geomorphology, 77, 126-141. https://doi.org/10.1016/j.geomorph.2005.12.010

Chossiere, G., Xu, H., Dixit, Y., Isaacs, S., Eastham, S., Allroggen, F., Speth, R. \& Barrett, S. 2021. Air pollution impacts of COVID-19-related containment measures. Science advances, 7 .

Collivignarelli, M.C., Abbà, A., Bertanza, G., Pedrazzani, R., Ricciardi, P., Miino, M.C., 2020. Lockdown for CoViD-2019 in Milan: what are the effects on air quality? Sci. Total Environ. 732, 139280. doi:10.1016/j.scitotenv.2020.139280

Cui, Y., Zhang, Z.-F., Froines, J., Zhao, J., Wang, H., YU, S. \& Detels, R. 2003. Air pollution and case fatality of SARS in the People's Republic of China: An ecologic study. Environmental health : a global access science source, 2, 15.

Environment Public Authority. 2011. Air Quality Status. Retrieved March 17, 2021, from enterprise.emisk.org/eMISKAirQuality/?locale=ar\#/KAQI

Environment Public Authority. 2021. Our Environmental Status. Retrieved June 18, 2020, from enterprise.emisk.org/eMISKAirQuality/?locale=ar\#/

Gasana, J., Shehab, M., 2020. Coronavirus disease (COVID 19): handling challenges in Kuwait. Science 2, 63. doi:10.3390/sci2030063.

Garg, A., Kumar, A. \& Gupta, N. C. 2020. Comprehensive Study on Impact Assessment of 
Lockdown on Overall Ambient Air Quality amid COVID-19 in Delhi and its NCR, India. Journal of Hazardous Materials Letters, 2, 100010.

Hashim, B.M., Al-Naseri, S.K., Al-Maliki, A., Al-Ansari, N., 2020. Impact of

COVID-19 lockdown on NO2, O3, PM2. 5 and PM10 concentrations and assessing air quality changes in Baghdad, Iraq. Sci. Total Environ. 754, 141978. doi:10.1016/j.scitotenv.2020.141978.

Hellewell, J. Abbott, S. Gimma, A. Bosse, N.I. Jarvis, C.I. Russell, T.W. Munday, J.D. Kucharski, A.J. Edmunds, W.J. Funk, S. et al. 2020. Feasibility of controlling COVID-19 outbreaks by isolation of cases and contacts. Lancet Glob.Health, 8, 488-496. [CrossRef]

JI, J. \& CHANG, R. 2020. Air quality changes and Grey relational analysis of pollutants exceeding standards during the COVID-19 pandemic in Wuhan.

Jiang, F., Deng, L., Zhang, L., Cai, Y., Cheung, C. \& Xia, Z. 2020. Review of the Clinical Characteristics of Coronavirus Disease 2019 (COVID-19). Journal of General Internal Medicine, 35.

Kaplan, E.H. 2020. Containing 2019-nCoV (Wuhan) coronavirus. Health Care Manag. Sci, 395, 497-506. [CrossRef] [PubMed]

Kerimray, A., Baimatova, N., Ibragimova, O.P., Bukenov, B., Kenessov, B., Plotitsyn, P., Karaca, F., 2020. Assessing air quality changes in large cities during COVID-19 lock downs: the impacts of traffic-free urban conditions in Almaty. Kazakhstan. Sci. Total Environ. 730, 139179. doi:10.1016/j.scitotenv.2020.139179.

Lu, H., Stratton, C. \& Tang, Y.-W. 2020. Outbreak of Pneumonia of Unknown Etiology in Wuhan China: the Mystery and the Miracle. Journal of Medical Virology, 92.

Hassam Aldashti et al. 2012. Kuwait second National Communications. http://data.beatona.net/dataset/65c9fc2c-f2ef-4076-b56d cc00d7c30e6e/resource/b3b83b00-ce82-4755-925b-a69bf40cfdf7/download/initialnational-communication-for-state-of-kuwait.pdf

Hassan Aldashti et al. 2019. Kuwait second National Communications. http://data.beatona.net/dataset/65c9fc2c-f2ef-4076-b56dcc00d7c30e6e/resource/b3b83b00-ce82-4755-925b-a69bf40cfdf7/download/initialnational-communication-for-state-of-kuwait.pdf

McTainsh, G. H., \& Pitblado, J. R. 1987. Dust storms and related phenomena measured from meteorological records in Australia. Earth Surface Processes and Landforms, 12(4), 415424. https://doi.org/https://doi.org/10.1002/esp.3290120407

Merlone, A., Al-Dashti, H., Faisal, N., Cerveny, R. S., AlSarmi, S., Bessemoulin, P., Brunet, M., Driouech, F., Khalatyan, Y., Peterson, T. C., Rahimzadeh, F., Trewin, B., Wahab, M. M. A., Yagan, S., Coppa, G., Smorgon, D., Musacchio, C., \& Krahenbuhl, D. 2019. Temperature extreme records: World Meteorological Organization metrological and 
meteorological evaluation of the $54.0^{\circ} \mathrm{C}$ observations in Mitribah, Kuwait and Turbat, Pakistan in 2016/2017. International Journal of Climatology, 39(13), 5154-5169. https://doi.org/https://doi.org/10.1002/joc.6132

Mahato, S., Pal, S., Ghosh, K.G. 2020. Effect of lockdown amid COVID-19 pandemic on air quality of the megacity Delhi, India. Sci. Total Environ. 730, 139086. doi:10.1016/j.scitotenv.2020.139086

Menut, L., Bessagnet, B., Siour, G., Mailler, S., Pennel, R., Cholakian, A. 2020. Impact of lockdown measures to combat Covid-19 on air quality over western Europe. Sci. Total Environ. 741, 140426. doi:10.1016/j.scitotenv.2020.140426.

MOH. COVID 19 Updates. 2020. Retrieved August 8, 2021, from: https://corona.e.gov.kw/En/

Musashi, J. P., Pramoedyo, H., \& Fitriani, R. 2018. Comparison of Inverse Distance Weighted and Natural Neighbor Interpolation Method at Air Temperature Data in Malang Region. CAUCHY - JURNAL MATEMATIKA MURNI DAN APLIKASI, 5(2), 48-54.

Neelamani, S., Al-Awadi, L., Al-Shatti, F., Al-Khaldi, M., Abdullah, M., \& Hussain, M. 2014. Extreme Wind and Gust Speed at the Territorial Waters of Kuwait, Arabian Gulf. Wind Engineering, 38(1), 39-71. https://doi.org/10.1260/0309-524X.38.1.39

Neelamani, S., Al-Sudairawi, M., Al-Dousari, A. \& Al-Dousari, N. 2015. Probability distribution and extreme value analysis of total suspended particulate matter in Kuwait. Arabian Journal of Geosciences, 8.

Ogen, Y. 2020. Assessing nitrogen dioxide (NO2) levels as a contributing factor to coronavirus (COVID-19) fatality. Science of The Total Environment, 726, 138605.

Quilty, B.J. Cli ord, S. Flasche, S. Eggo, R.M. 2020. Effectiveness of airport screening at detecting travellers infected with novel coronavirus (2019-nCoV). Eurosurveillance, 25, 2000080. [CrossRef] [PubMed]

Şahin, M., 2020. The association between air quality parameters and COVID-19 in Turkey.

Pharm. Biomed. Res. 6, 49-58 http://dx.doi.org/10.18502/pbr.v6i(s1).4402.

Sasidharan, M., Singh, A., Torbaghan, M. E. \& Parlikad, A. K. 2020. A vulnerability-based approach to human-mobility reduction for countering COVID-19 transmission in London while considering local air quality. Science of The Total Environment, 741, 140515.

Sannino, A., D’Emilio, M., Castellano, P., Amoruso, S. \& Boselli, A. 2020. Analysis of Air Quality during the COVID-19 Pandemic Lockdown in Naples (Italy). Aerosol and Air Quality Research, 20.

Shakoor, A., Chen, X., Farooq, T.H., Shahzad, U., Ashraf, F., Rehman, A., e Sahar, N., Yan, W. 2020. Fluctuations in environmental pollutants and air quality during the lockdown in the USA and China: two sides of COVID-19 pandemic. Air Qual. Atmos. Health 13, 13351342. doi:10.1007/s11869-020-00888-6. 
Tobías, A., Carnerero, C., Reche, C., Massagué, J., Via, M., Minguillón, M.C., Alastuey, A., Querol, X. 2020. Changes in air quality during the lockdown in Barcelona (Spain) one month into the SARS-CoV-2 epidemic. Sci. Total Environ. 726, 138540. doi:10.1016/j.scitotenv.2020.138540.

Saeed, T M, Al-Dashti, H., \& Spyrou, C. 2014. Aerosol's optical and physical characteristics and direct radiative forcing during a shamal dust storm, a case study. Atmospheric Chemistry and Physics, 14(7), 3751-3769. https://doi.org/10.5194/acp-14-3751-2014

Saeed, Thuraya M, \& Al-Dashti, H. 2011. Optical and physical characterization of "Iraqi freedom" dust storm, a case study. Theoretical and Applied Climatology, 104(1), 123137. https://doi.org/10.1007/s00704-010-0334-3

Watson, D. F., \& Philip, G. M. 1985. A Refinement of Inverse Distance Weighted Interpolation. Geoprocessing, 2(4), 315-327. Retrieved from https://www.semanticscholar.org/paper/Arefinement-of-inverse-distance-weightedWatson/05460f45dedb446b391889138aef84074986aead

Wu, X., Nethery, R., Benjamin, M., Braun, D. \& Dominici, F. 2020. Exposure to air pollution and COVID-19 mortality in the United States: A nationwide cross-sectional study.

Xu, Z., Shi, L., Wang, Y., Zhang, J., Huang, L., Zhang, C., Liu, S., Zhao, P., Liu, H., Zhu, L., Tai, Y., Bai, C., Gao, T., Song, J.-W., Xia, P., Dong, J., Zhao, J. \& Wang, F.-S. 2020. Pathological findings of COVID-19 associated with acute respiratory distress syndrome. The Lancet Respiratory Medicine, 8.

Yassin, M., Malek, M. \& A-Rashidi, M. 2018. Ozone background levels and trends in the state of Kuwait.

Yuan, Y., Alahmad, B., Kang, C.-M., Al-Marri, F., Kommula, V., Bouhamra, W., \& Koutrakis, P. 2020. Dust Events and Indoor Air Quality in Residential Homes in Kuwait. International Journal of Environmental Research and Public Health, 17(7). https://doi.org/10.3390/ijerph17072433

Zhu, Y., Xie, J., Huang, F. \& Cao, L. 2020. Association between short-term exposure to air pollution and COVID-19 infection: Evidence from China. Science of The Total Environment, 727, 138704. 
